総説

\title{
モノマーの構造と反応性 経験的パラメータとラジカル重合反応性
}

\section{大津 隆 行*}

Structure and Reactivity of Monomers

Relationship between Empirical Parameters

and Radical Polymerization Reactivities

Takayuki Orsu*

I.はじめに

ビニルモノマーのラジカルおよびイオン重合は，それ ぞれ次の上うに表わされる。

$$
\begin{aligned}
& \cdots \mathrm{CH}_{2}-\dot{\mathrm{C}} \mathrm{H}+\mathrm{CH}_{2}=\mathrm{CH} \\
& \mathrm{X} \quad \mathrm{X}
\end{aligned}
$$

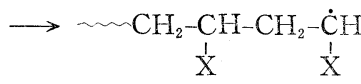

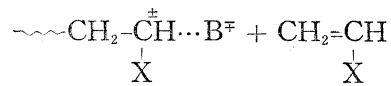

$$
\begin{aligned}
& \longrightarrow \underset{\mathrm{CH}_{2}-\mathrm{CH}-\mathrm{CH}_{2}{ }^{ \pm} \mathrm{CH} \cdots \mathrm{B}^{\mp}}{\mathrm{X}} \stackrel{\mathrm{X}}{\mathrm{X}}
\end{aligned}
$$

ラジカル重合では生長反応のおこりやすさ（モノマー の反応性）江用いた開始剤や溶媒などに関係なく，モノ マーの構造によってきめられる。したがって，一般にビ ニルニノマーの構造と反応性の関係を定量化することは 容易である。これに対してイオン重合ではモノマーの反 応性法モアマーの構造はもちろん, 対イオン（開始剤で きまる) ならびに溶媒によっても変化するので，モノマ 一の構造と反忘性の関係を定量化することは容易でな い。しかし高分子合成の立場からはこの反忘を規制する 因子が多いだけ後者の方が興味深い。

ラジカル共重合のデータにもとづいて，ビニルモノマ 一の檴造とラジカル重合反応性の取り扱いには, Alfrey,

* 大阪市立大学工学部応用化学科

* Department of Applied Chemistry, Faculty of Engineering, Osaka City University
Price (1947 年) によるQ, $e_{\text {論 }}^{1 \sim 3)}$ と, Hammett (1937

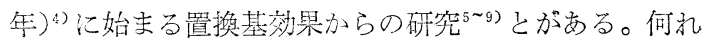
もモノマー亦るいはその置推基の極性ならびに共鳴効果 の観点より取り扱うものである。なかでも前者は広くビ ニルモノマーの重合反応性の説明や予測に用いられてい る。本稿では，この両者の取り扱いと最近の発展ならび にお互いの関連性をのべると其に，これらをもとにして 導かれた経験的パラメータを用いてラジカル重合反応性 を評価する陚多などについてのべることに与る。なお， モノマー反忘性の理諭的取り技いやイオン重合反応性に ついては本稿では报わない目目方。

\section{II. $Q, e$ の取り圾い，ならびにそれからみ} たモノマーの構造と反応性

1. $\boldsymbol{Q}, \boldsymbol{e}$ の取り扱い Alfrey, Price は式〔1]の生 長反店の速度定数 $\left(k_{12}\right)$ が式〔2】で表わされると仮定し $た^{1 \sim^{3)}}$ 。

$$
\begin{array}{r}
\mathrm{M}_{1} \bullet+\mathrm{M}_{2} \stackrel{k_{12}}{\longrightarrow} \mathrm{M}_{2} \bullet \cdots \ldots \\
k_{12}=P_{1} Q_{2} \exp \left\{-e_{1} e_{2}\right\}
\end{array}
$$

ここで, $P_{1}$ は $\mathrm{M}_{1}$ ・の共鳴安定化， $Q_{2}$ は $\mathrm{M}_{2}$ の共鳴安 定化， $e_{1}$ および $e_{2}$ はそれぞれ $\mathrm{M}_{1}$ ・および $\mathrm{M}_{2}$ の極性効 果を表わす。式〔2]の関係をラジカル共重合におけるモ ノマ一反応性比に代入すると，式〔3】および〔4】が得ら れる。

$$
\begin{aligned}
& \mathrm{r}_{1}=\frac{k_{11}}{k_{12}}=\frac{Q_{1}}{Q_{2}} \exp \left\{-e_{1}\left(e_{1}-e_{2}\right)\right\} \\
& \mathrm{r}_{2}=\frac{k_{22}}{k_{21}}=\frac{Q_{2}}{Q_{1}} \exp \left\{-e_{2}\left(e_{2}-e_{1}\right)\right\}
\end{aligned}
$$

ここで基準モノマーにスチレンそ選び，そのQおよび 
$e$ 值を 1.0 および -0.8 と仮定し，さらにモノマーとそ のラジカルの $e$ 值が等しいと仮定すると，式〔3]拉よび [4]を用いて多くのモノマーの $Q, e$ 值を計算すること ができる。このようにして求められた多くのモノマー (約 500) の $Q, e$ 值は Young ${ }^{14)}$ によってまとめられて いる。

以上のように $Q$ 抢よび $e$ 值はそれぞれモノマーの共鳴 㐫るいは極性効果の程度を表わす実験的パラメータであ る。これに理論的解釈を与える試みや，この取り扱いに 含まれる仮定を再検討する試みがなされているが，この ような点も本稿で法ふれない吕 17)。

\section{2. $\boldsymbol{Q}$ 值とモノマーの構造 $Q$ 值はスチレンを基準} (1.0) として求められたもので(これからエチレンの $Q=0.01 \sim 0.015$ となる)，一般值換基による立体効果 が無視できる限り置換基との共役の程度を示す值であ る。経験的には $Q$ が 0.2 以上のモノマーを共役モノマ 一，それ以下のモノマーを非共役モノマーとよんで区別 される。前者仙は置換基として $\mathrm{C}=\mathrm{C}, \mathrm{C}=\mathrm{O}, \mathrm{C} \equiv \mathrm{N}, \mathrm{NR}_{2}$, SR を含むモノマーが，後者にはそれ以外の置換基を含

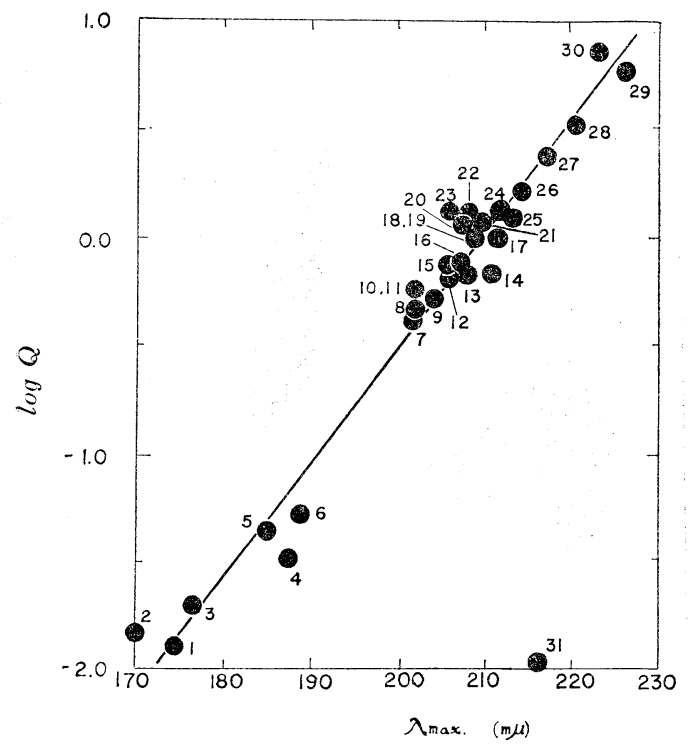

図1モノマーの $\log Q$ と $\lambda_{\max }$ の関係:

1. ブテン -1 , 2. エチレン, 3. ヘキセン-1，4. イソブテン, 5. 塩化ビニル，6.アリルアルコール，7. アクリル酸メチル, 8. アクリル酸イソプロピル，9.アクリル酸ベンジル，10.アク リル酸- $\beta$-クロロエチル，11。アクリロニトリル，12，又夕クリ 几酸-n-ブチル，13.メタクリル酸イソブチル，14.メチルビ二 ルケトン, 15. メタクリル酸メチル，16. メタクリル酸ベンジル， 17. スチレン, 18. メタクル酸- $\beta$-クロロエチル， 19.アクロレ イン, 20. メタクリル酸フェニル，21. メタクリル酸-pーメチルフ ェニル，22. メタクリル酸-pーメトキンフェニル，23.メタクリル 酸- $p$-クロロフェニル，24.メタクリル酸-m-クロロフェニル, 25. メタクリル酸- $p$-ニトロフェニル，26.メタクロレイン 27. ブタジエン, 28. イソプレン, 29.2,3-ジメチルブタジエン, 30. クロロプレン, 31 . クロトンアルデヒド
むモノマーが含まれる。また実験的にビニルモノマーの 紫外吸収スペクトルの吸収極大と $\log Q$ の間に直線関倸 （図 1）が成立することが見出されて初り ${ }^{18) ， こ れ か ら ~}$ $Q$ 值を予測することも可能である。

$Q$ 值はモノマー中の二重結合汇結合した置愌基の数上 結合位置に関して，とくに立体効果が働くよらな場合に は予想される值よりも小さく表われる。たとえば，フェ ニルチオエチレン誘導体については次のような $Q, e$ 值 が求められている19)。

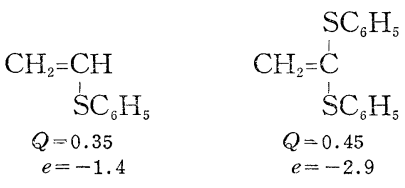

$$
\begin{aligned}
& \mathrm{SC}_{6} \mathrm{H}_{5} \\
& \mathrm{CH}=\mathrm{C} H \\
& \mathrm{SC}_{6} \mathrm{H}_{5} \\
& Q=0.056 \\
& e=-2.5 \\
& \mathrm{CH}=\mathrm{CH}
\end{aligned}
$$

1,1-シ㯰換体ではモノ置換体よりも $Q$ 值怯大きくなる が，1，2-ジ置換体で法著るしく小さくなる。同樣な傾向 はフェニルエチレン ${ }^{14)}$ ，ブテン ${ }^{20)}$ および篮化プロペニル 異性体モノマー ${ }^{21}$ についても認められて抢り，一般にテ ノマーの反応性は 1, 1-ジ置撸体>モノ置換体》1,2trans-ジ置換体 $\geq 1,2-$ - is-ジ置換体の順となる。

\begin{tabular}{|c|c|c|c|c|c|c|}
\hline $\mathrm{X}$ & Y & $\gamma_{1}$ & $\gamma_{2}$ & $e_{1}$ & $Q_{1}$ & 文献 \\
\hline $\mathrm{CN}$ & $\mathrm{OCH}_{3}$ & 0.35 & 0.35 & 0.40 & 0.72 & 26 \\
\hline $\mathrm{CN}$ & $\mathrm{CH}_{3}$ & 0.16 & 0.30 & 0.81 & 1.12 & 14 \\
\hline $\mathrm{CN}$ & $\mathrm{C}_{6} \mathrm{H}_{5}$ & 0.7 & 0.02 & 1.26 & 9.60 & 27 \\
\hline $\mathrm{CN}$ & $\mathrm{H}$ & 0.04 & 0.40 & 1.20 & 0.60 & 14 \\
\hline $\mathrm{CN}$ & $\mathrm{Cl}$ & 0.13 & 0.06 & 1.40 & 2.83 & 25 \\
\hline $\mathrm{CN}$ & $\mathrm{OCOCH}_{3}$ & 0.20 & 0.16 & 1.06 & 1.17 & 28 \\
\hline $\mathrm{CN}$ & $\mathrm{COOCH}_{3}$ & 0.03 & 0.01 & 2.1 & 12.6 & 24 \\
\hline $\mathrm{CN}$ & $\mathrm{CN}$ & 0.001 & 0.005 & 2.85 & 20.1 & 22 \\
\hline $\mathrm{COOCH}_{3}$ & $\mathrm{OCH}_{3}$ & 0.51 & 1.10 & 0.04 & 0.47 & 26 \\
\hline $\mathrm{COOCH}_{3}$ & $\mathrm{CH}_{3}$ & 0.50 & 0.50 & 0.40 & 0.74 & 14 \\
\hline $\mathrm{COOCH}_{3}$ & $\mathrm{C}_{6} \mathrm{H}_{5}$ & 0.19 & 0.04 & 1.41 & 4.28 & 29 \\
\hline $\mathrm{COOCH}_{3}$ & $\mathrm{H}$ & 0.18 & 0.75 & 0.60 & 0.42 & 14 \\
\hline $\mathrm{COOC}_{2} \mathrm{H}_{5}$ & $\mathrm{Cl}$ & 0.30 & 0.08 & 1.13 & 2.65 & 25 \\
\hline $\mathrm{COOC}_{2} \mathrm{H}_{5}$ & $\mathrm{Br}$ & 0.50 & 0.06 & 1.07 & 3.70 & 25 \\
\hline $\mathrm{COOC}_{2} \mathrm{H}_{5}$ & $\mathrm{OCOCH}_{3}$ & 0.20 & 0.57 & 0.67 & 0.54 & 30 \\
\hline $\mathrm{COOC}_{2} \mathrm{H}_{5}$ & $\mathrm{COOC}_{2} \mathrm{H}_{5}$ & 0.08 & 0.03 & 1.66 & 4.78 & 25 \\
\hline $\mathrm{COOCH}_{3}$ & $\mathrm{CN}$ & 0.03 & 0.01 & 2.1 & 12.6 & 24 \\
\hline
\end{tabular}

1,1-ジ置換モノマー 2 つの置換基がいず杞も共役基 であるモノマー，たとえばビニリデンシアニド22)， c-シ アノアクリル酸メチル 23,24)の場合には異常に大きいQ値 分観察される。山田, 大津 ${ }^{25)}$ は数種の $い$-置換アクリル

表 1 スチレン $\left(\mathrm{M}_{2}\right)$ とのラジカル共重合 $\left(60^{\circ} \mathrm{C}\right)$ に 扮ける 1,1-ジ置換モノマー $\left(\mathrm{CH}_{2}=\mathrm{CXY} ; \mathrm{M}_{1}\right)$ の共重合パラメータ 
酸エステルおよび $\propto-$ 置換アクリロニトリルとスチレン の共重合を行ない，表 1 の結果をまとめた。この結果か ら，これら 1,1-ジ置換モノマー，

$$
\mathrm{CH}_{2}=\mathrm{C}^{\prime \mathrm{X}}
$$

$の Q$ 值は相当するモノ置換モノマーのQ 值と式 [5]〜 〔6〕の関係で表わされる。

$$
\begin{aligned}
\log Q_{\mathrm{CH}_{2}=\mathrm{C}}\left\langle_{\mathrm{Y}}^{\mathrm{X}}\right. & =\log Q_{\mathrm{CH}_{2}=\mathrm{C}}\left\langle_{\mathrm{Y}}^{\mathrm{H}}\right. \\
& +\left(\log Q_{\mathrm{CH}_{2}=\mathrm{C}}\left\langle_{\mathrm{H}}^{\mathrm{X}}-\log Q_{\mathrm{CH}_{2}=\mathrm{CH}}\right)\right. \\
& =\log Q_{\mathrm{CH}_{2}=\mathrm{C}}\left\langle_{\mathrm{Y}}^{\mathrm{H}}+\Delta \log Q_{\mathrm{X}} \cdots \cdots \cdots[5]\right. \\
\log Q_{\mathrm{CH}_{2}=\mathrm{C}}\left\langle_{\mathrm{Y}}^{\mathrm{X}}\right. & =\log Q_{\mathrm{CH}_{2}=\mathrm{C}}\left\langle_{\mathrm{H}}^{\mathrm{X}}\right. \\
& +\left(\log Q_{\mathrm{CH}_{2}=\mathrm{C}}\left\langle_{\mathrm{H}}^{\mathrm{X}}-\log Q_{\mathrm{CH}_{2}=\mathrm{CH}_{2}}\right)\right. \\
& =\log Q_{\mathrm{CH}_{2}=\mathrm{C}}\left\langle_{\mathrm{H}}^{\mathrm{X}}+\Delta \log Q_{\mathrm{Y}} \cdots \cdots \cdots[6]\right.
\end{aligned}
$$

ここで, $\Delta \log Q_{\mathrm{X}}$ および $\Delta \log Q_{\mathrm{Y}}$ はそれぞれエチレ ンに1つの置換基（XあるいはY）が導入された場合 にみられる $\log Q$ の増加量であり, $\mathrm{X}$ あるいは $\mathrm{Y}$ 置換 基による共鳴効果をしめす。これら值は 既報の $Q$ 值を 用いて計算することができる（表 2 ${ }^{25)}$ 。したがって式 [5],[6]から 1,1-ジ置換モノマーの $Q$ 值を予測できる が，これらモノマーのなかには天井温度の低いものが多 いために制約は避けられない。

褩 2 式[5]あるいは〔6]における $\Delta \log Q$ 值

\begin{tabular}{c|l||l|l}
\hline $\mathrm{X}$ あるいは & $\Delta \log Q$ & $\mathrm{X}$ あるいは & $\Delta \log Q$ \\
\cline { 1 - 3 } $\mathrm{CH}_{3} \mathrm{O}$ & 0.06 & $\mathrm{Br}$ & 0.95 \\
$\mathrm{CH}_{2}$ & 0.26 & $\mathrm{OCOCH}_{3}$ & 0.20 \\
$\mathrm{H}$ & 0 & $\mathrm{COOCH}_{3}$ & 1.19 \\
$\mathrm{Cl}$ & 0.74 & $\mathrm{CN}$ & 1.50 \\
\hline
\end{tabular}

式〔5】および〔6】の成立（ならびに後述する式〔7〕お よび〔8]の成立) は $\alpha$-置換アクリル酸エステルおよび アクリロニトリルの反応性が置換基の共鳴と極性効果で 表わされることを意味する。しかし 果が重要な場合もある。たとえば $\alpha$-置換基の共鳴と極 性効果があまり変化せず，立体的な嵩高さの異なるよう なアルキル置換体については相対的に立体効果が重要と なる (III. 7 参照)。

1,2-ジ置換モノマーこの場合には置換基による立体 効果のために単独および共重合性はきわめて小さく, $Q$ 值も相当する 1,1-ジ置換モノマーあるいは モノ置換モ ノマーより小さくなる。たとえば， $\beta$ アアルキル置換スチ レンの反応性は相当する $\propto$-アルキルスチレンの $1 / 10$

\begin{tabular}{|c|c|c|c|c|c|}
\hline \multirow{2}{*}{$\begin{array}{c}\text { 置 } \\
\mathrm{X}\end{array}$} & 基 & \multirow{2}{*}{ 異性体 } & \multirow{2}{*}{$Q$} & \multirow{2}{*}{$e$} & \multirow{2}{*}{ 文 献 } \\
\hline & $\mathrm{Y}$ & & & & \\
\hline \multirow{2}{*}{$\mathrm{CH}_{3}$} & \multirow[t]{2}{*}{$\mathrm{CH}_{3}$} & trans & 0.004 & -1.06 & 20 \\
\hline & & cis & 0.004 & -0.98 & 20 \\
\hline \multirow[t]{2}{*}{$\mathrm{CH}_{3}$} & \multirow[t]{2}{*}{$\mathrm{Cl}$} & trans & 0.009 & -1.33 & 21 \\
\hline & & cis & 0.005 & -1.66 & 21 \\
\hline \multirow[t]{2}{*}{$\mathrm{Cl}$} & \multirow[t]{2}{*}{$\mathrm{Cl}$} & trans & 0.01 & 1.28 & 14 \\
\hline & & cis & 0.003 & 1.25 & 14 \\
\hline \multirow[t]{2}{*}{$\mathrm{CH}_{3}$} & \multirow[t]{2}{*}{$\mathrm{C}_{6} \mathrm{H}_{5}$} & trans & 0.052 & -1.30 & 32 \\
\hline & & cis & 0.029 & -0.92 & 32 \\
\hline \multirow[t]{2}{*}{$\mathrm{C}_{6} \mathrm{H}_{5}$} & \multirow[t]{2}{*}{$\mathrm{C}_{6} \mathrm{H}_{5}$} & trans & 0.03 & -0.08 & 14 \\
\hline & & cis & 0.013 & -0.03 & 14 \\
\hline \multirow[t]{2}{*}{$\mathrm{SC}_{6} \mathrm{H}_{5}$} & \multirow[t]{2}{*}{$\mathrm{SC}_{6} \mathrm{H}_{5}$} & trans & 0.056 & -2.5 & 19 \\
\hline & & cis & 0.026 & -2.3 & 19 \\
\hline \multirow[t]{2}{*}{$\mathrm{COOC}_{2} \mathrm{H}_{5}$} & \multirow[t]{2}{*}{$\mathrm{COOC}_{2} \mathrm{H}_{5}$} & trans & 0.61 & 1.25 & 14 \\
\hline & & cis & 0.059 & 1.49 & 14 \\
\hline \multirow[t]{2}{*}{$\mathrm{COOCH}_{3}$} & \multirow[t]{2}{*}{$\mathrm{COOC}_{6} \mathrm{H}_{5}$} & trans & 0.76 & 1.49 & 14 \\
\hline & & & 0.09 & 1.27 & 14 \\
\hline
\end{tabular}

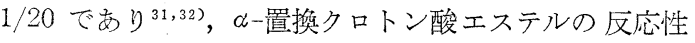

は $\alpha$-置換アクリル酸エステルの約 $1 / 20$ である ${ }^{33)}$ 。また, cis および trans 異性体を比較すると，一般に反応性は 後者の方が大で，したがってQ值も大きくなる（表 3）。

表 3 1,2-ジ置換モノマー (CHX=CHY) の cis およ び trans 体の $Q, e$ 值

3. $e$ 值टモノマーの構造 モノマーの $e$ 值はそれ に含まれる置換基による二重結合の電子密度を表わし, 置換基が電子吸引性ならば負の $e$ 值，電子受容性ならば 正の $e$ 值を示す。古川，鶴田 ${ }^{34)}$ はモノマーの $e$ 值とその 置換基の Hammett の $\sigma$ 值との間に直線関係のあること を見出している。仮定からスチレンの $e$ 值は -0.8 とお かれているが，フェニル置換基の $\sigma$ 值は -0.01 である 点に留意する必要がある。

式〔5]および〔6]と同㴍に，1,1-ジ置換モノマー， と くに $\alpha$-置換アクリル酸エステルおよびアクリロニトリ ルの $e$ 值は式〔7〕あるいは[8]の関係で表わされる ${ }^{25)} 。$

$$
\begin{aligned}
e_{\mathrm{CH}_{2}=\mathrm{C}}\left\langle_{\mathrm{Y}}^{\mathrm{X}}\right. & =e_{\mathrm{CH}_{2}=\mathrm{C}}<_{\mathrm{Y}}^{\mathrm{H}}+2.4 \sigma_{\mathrm{X}} \\
& =e_{\mathrm{CH}_{2}=\mathrm{C}}<_{\mathrm{H}}^{\mathrm{x}}+2.4 \sigma_{\mathrm{Y}}
\end{aligned}
$$

ここで， $\sigma_{\mathrm{X}}$ および $\sigma_{\mathrm{Y}}$ はそれぞれ $\mathrm{X}$ および $\mathrm{Y}$ 置換基 の Hammett の置換基定数である。式〔7】，〔8】はこれら モノマーの $e$ 值を予測するのに用いることができる。同 様に，1,2-ジ置換モノマーについても置換基の極性効果 に加成性のあることがわかる（表 3 参照）。

\section{4. $Q, e$ 值亡モノマーの反応性}

i. $Q$ 值亡速度定数の関係 数種のモノマーの $Q, e$ 值 とこれらモノマーのポリマーラジカルに対する反応の速 度定数の関係を表 4 によ放 ${ }^{35)}$ 。表 4 からモノマーの 反応性は $e$ 值に殆んど関係なく, $Q$ 值に比例しているこ 
表 4 種々のモノマーおよびそのラジカルとの反応の速度定数 $\left(60^{\circ} \mathrm{C}\right)$

\begin{tabular}{|c|c|c|c|c|c|c|c|c|c|c|}
\hline モ & $\nabla$ & - & & ポ & $\checkmark$ & - & ラ & ジ & ル & \\
\hline & $Q$ & $e$ & 䤀酸ビニル & 塩化ビニル & $\mid \begin{array}{l}\text { フクリル } \\
\text { 酸メチル }\end{array}$ & $\begin{array}{l}\text { アクリロ } \\
\text { ニトリル }\end{array}$ & $\mid \begin{array}{c}\text { メタクリル } \\
\text { 酸メチル }\end{array}$ & $\begin{array}{l}\text { メタクリロ } \\
=ト リ ル ル \mid\end{array}$ & スチレン & ブタジェン \\
\hline 䣫 酸 ビ = ル & 0.026 & -0.22 & 2040 & 6150 & 140 & 104 & 29 & 16 & 3.3 & - \\
\hline 塩 化 ビ = ル & 0.044 & 0.20 & 6800 & 12900 & 250 & 130 & 48 & - & 10 & - \\
\hline アクリル 酸メチル & 0.42 & 0.6 & 20000 & 160000 & 1250 & 一 & - & - & 230 & - \\
\hline アクリロニトリル & 0.60 & 1.2 & 30000 & 650000 & - & 425 & 425 & - & 435 & 300 \\
\hline メタクリル酸メチル & 0.74 & 0.4 & 200000 & - & - & 2350 & 575 & 290 & 340 & 140 \\
\hline メタクリロニトリル & 1.0 & 1.0 & 200000 & - & - & - & 860 & 190 & 590 & 290 \\
\hline ス チ レ ン & 1.0 & -0.8 & 200000 & 650000 & 7000 & 10000 & 1250 & 760 & 178 & 75 \\
\hline ブ タ ジ エン & 2.39 & -1.05 & - & - & - & - & 2300 & - & 220 & 105 \\
\hline
\end{tabular}

とがわかる。すなわち，一般にQ值の大きい共役モノマ 一ではラジカルと容易に反応するが，非共役モノマーで は反応性は小さい。また，モノマーに対するラジカルの 反応性は共役モノマーから生成するラジカルの方が，非 共役モノマーから生成するラジカルより小さい。いいか えるとモノマーとラジカルの反応性に逆比例関係のある ことがわかり，重合反応性に重要な役割を演ずる（II. 4. iii 参照)。

ii. $\boldsymbol{e}$ 值と速度定数の関係 表 4 亿示した反応速度定 数はモノマーの $e$ 值と值接関係はない。しかしQ值があ まり変化しない共役モノマーあるいは非共役モノマーの 間で，しかも立体効果の働かないときには，反応性のち がいは $e$ 值によって説明される場合が多い。式〔3〕およ び〔4】のモノマー反応性比の積をとると，式〔9]が導か 孔る。

$$
\gamma_{1} \gamma_{2}=\exp \left\{-\left(e_{1}-e_{2}\right)^{2}\right\}
$$

したがって，両モノマーの $e$ 值の差が大きければ交互 共重合反忘性の大きいことがわかり，Q值があまり変化 しない共重合系ではこの関係が成立する。

しかし，無水マレイン酸のように強い電子受容性モ， マーは電子供与性モノマーたとえばビニルエーテル，ビ ニルスルフィド， と交互共重合を行ならことが知られているるこの場 合，次に示すような，極性遷移状態を形成して交互生長 の活性化エネルギーを低下させるためと説明されてき $た^{37,38)}$ 。しかし，このような考えが発表された当時から

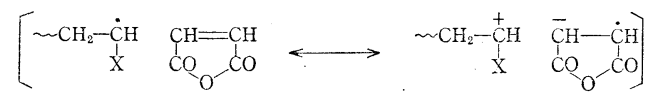

あるいは

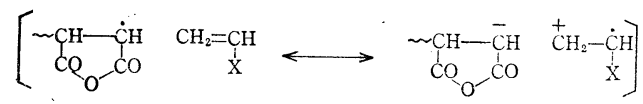

交互共重合を行なうモノマー間で錯体の生成が考慮され ていたが391, 山下ら ${ }^{39,40)}$ は $p$-ジオキセンと無水マレイ
ン酸などの系で次のような電荷移動錯体の告成京確か

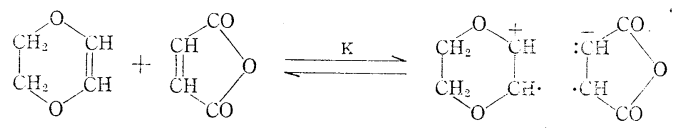

め，このような錯体が 1 つのモノマーとして交互共重合 すると仮定して錯体モノマーの反応性の評価を行なって

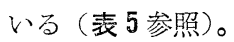

この場合, 形成される電荷移動錯体の平衡定数が重要 であり，これが小さいときには電荷移動錯体の関与をほ とんど無視できると思われる（䢅密には三元共重合とし て取り扱うべきである)。たとえば電子供与性のビニル スルフィドとビニルエーテル (いずれも $K=10^{-2} l$, $\mathrm{mol}^{-1}$ ) は共に無水マレイン酸と交互共重合を行なう が41a)，ポリ無水マレイン酸ラジカルを含就て他の多く のポリマーラジカルに対するビニルエーテルとビニルス ルフィドの選択反応性は用いたポリマーラジカルの極性

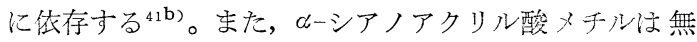
水マレイン酸と同程度の $e$ 值をもつが， $Q$ 值は大きく異 なる (表 1 参照)。このものは電子供与性の共役こノマ 一（たとえばスチレン）と無開始剤で交互共重合安行な らが，非共役モノマー（たとえばビニルエーテルなど） と汸 $0^{\circ} \mathrm{C}$ で混合するだけで重合が沶こり交互共重合体沈 生成しない（ほとんど ひ-シアノアクリル酸メチルより なるポリマーが生成する $)^{42)}$ 。単独重合性とQ 佪のち㤎 いによると思われる。

特定のポリマーラジカルに対して置換基だけがことな る一連のモノマーの反応性は共鳴効果を考慮した Hammett 式促うが，逆侍特定のモノマーに刘するポリマ 一ラジカルの反応性注極性のみを考慮した Hammett 式 に従う。この点は次章でのべる。また, $p$-置換スチレ ン43)およ゙゙メタクリル酸アルキル44)の祅はそれぞれ Hammett の $\sigma$ 值および Taft 式の $\sigma^{*}$ 值と直線関俰仙㐫 ることが見出されている(図2および3)。いずれもの㐫

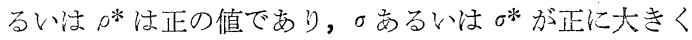




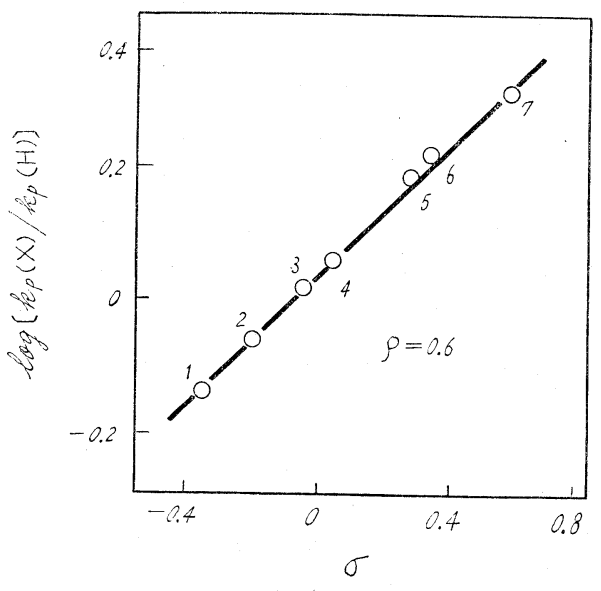

図 $2 p$-置換スチレンの $k_{p}$ とハメットの $\sigma$ の関係 $\left(30^{\circ} \mathrm{C}\right)$;

1. $\mathrm{OCH}_{3}, 2 . \mathrm{CH}_{3}, 3 . \mathrm{H}, 4 \mathrm{~F} .5 . \mathrm{Cl}, 6 . \mathrm{Br}$, 7. $\mathrm{CN}$

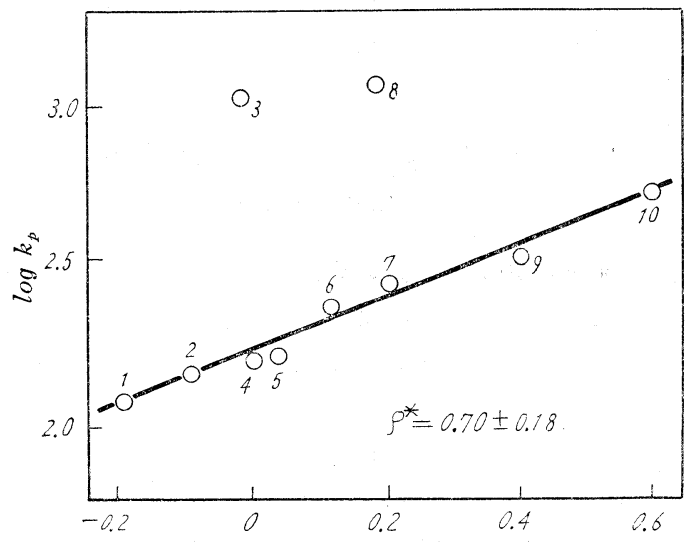

図 3 メタクリル酸アルキルの $k_{p}$ とエステルアル キル基の $\sigma^{*}$ の関係

1. $i-\mathrm{C}_{3} \mathrm{H}_{7}, 2 . \mathrm{C}_{2} \mathrm{H}_{5}$, 3. $\mathrm{C}_{6} \mathrm{H}_{11} \mathrm{CH}_{2} \mathrm{CH}_{2}$, 4. $\mathrm{CH}_{3}$,

5. $\mathrm{C}_{6} \mathrm{H}_{5} \mathrm{CH}_{2} \mathrm{CH}_{2} \mathrm{CH}_{2}$, 6. $\mathrm{C}_{6} \mathrm{H}_{5} \mathrm{CH}_{2} \mathrm{CH}_{2}$, 7. $\mathrm{CH}_{3} \mathrm{OCH}_{2} \mathrm{CH}_{2}$,

8. $\mathrm{C}_{6} \mathrm{H}_{5} \mathrm{CH}_{2}, 9 . \mathrm{ClCH}_{2} \mathrm{CH}_{2}, \quad 10 . \mathrm{C}_{6} \mathrm{H}_{5}$

なる（モノマーの $e$ としては正に大）ほど なる。簡単に梳生長反応の萲移状態における静電的反搏 が低下するためと説明することができるだろう。

iii. $Q$ とeの関係ならびにそれらの変化 Alfrey,

Priceによるモノマーの $Q$ と $e$ の間に淔接的な関係は

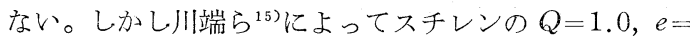
0 と仮定して再計算された $Q, e$ 值では，お互いの間に 共役モノマーおよび非共役モノマーについてそれぞれ別 の直線関係のあることが見出されている。

一般に，モノマーの $Q, e$ 做はそれに固有の值であり， 反応条件などによって変化しない(17)。しかしある種のモ ノマーが解離性，または添加物と錯体を形成するような 場合には見掛上変化させることができる45 证。たとえ
ば, $\mathrm{ZnCl}_{2}, \mathrm{SnCl}_{4}$ のようなルイス酸は極性モ/マーと 錯体を形成する。

$$
\begin{aligned}
\mathrm{CH}_{2}=\mathrm{CHCN}+\mathrm{SnCl}_{4} \stackrel{K_{1}}{\rightleftharpoons} \mathrm{CH}_{2}=\mathrm{CHCN} \cdot \mathrm{SnCl}_{4} \\
\mathrm{CH}_{2}=\mathrm{CHCN} \cdot \mathrm{SnCl}{ }_{4}+\mathrm{CH}_{2}=\mathrm{CHCN} \\
\stackrel{K_{2}}{\rightleftharpoons}\left(\mathrm{CH}_{2}=\mathrm{CHCN}\right)_{2} \mathrm{SnCl}_{4}
\end{aligned}
$$

ただし， $K_{1}=2.0 \pm 0.1, K_{2}=1.0 \pm 0.1 \mathrm{~mol} / l$ (ペンゼン中， $\left.20 \sim 25^{\circ} \mathrm{C}\right)^{48)}$

錯体形成能をもたないモノマーとの其重合データから 求められた錯体モノマーの見掛けの $Q, e$ 值党 5 に京 とめる。同表には交互共重合を行なうモノマ一間の電荷 移動錯体 (II. 4. iv 参照) についての值も示した ${ }^{40 \mathrm{~b}) 。 ル ~}$ イス酸との錯体形成によってモノマーの $Q, e$ 值はとも に増大し，とくに電子受容性の増大することがわかる。 古くからルイス酸存在下で極性モノマーがオレフィン類 と共重合しやすくなることが知られていたが52,53)，最 近，このようなルイス酸錯体はオレフィンやジエンなど と交互共重合を行なうことが見出され，注目をよんでい

\begin{tabular}{|c|c|c|c|}
\hline 錯体モノマ一 & $Q$ & $e$ & 文 献 \\
\hline $\mathrm{MMA}-\mathrm{ZnCl}_{2}$ & 26.3 & 4.2 & 45 \\
\hline $\mathrm{MMA}_{-} \mathrm{SnCl}_{4}$ & $2 \sim 4$ & $0.4 \sim 1.0$ & 49 \\
\hline $\mathrm{EA}-\mathrm{SnCl}_{4}$ & 3.58 & 1.92 & 49 \\
\hline $\mathrm{AN}-\mathrm{ZnCl}_{2}$ & 12.6 & 8.2 & 47 \\
\hline $\mathrm{AN}-\mathrm{SnCl}_{4}$ & 2.64 & 2.22 & 49 \\
\hline $\mathrm{MVP}-\mathrm{ZnBr}_{2}$ & 0.84 & 0.73 & 50 \\
\hline $\mathrm{E}-\mathrm{AgNO}_{3}$ & 29.5 & 1.66 & 51 \\
\hline PD-MAn & 2.4 & 0.98 & $40 \mathrm{~b}$ \\
\hline CEVE-MAn & 2.2 & 0.31 & $40 \mathrm{~b}$ \\
\hline MMA & 0.74 & 0.40 & 14 \\
\hline EA & 0.52 & 0.22 & 14 \\
\hline $\mathrm{AN}$ & 0.60 & 1.20 & 14 \\
\hline MVP & 0.86 & -0.56 & 14 \\
\hline $\mathrm{E}$ & 0.015 & -0.20 & 14 \\
\hline
\end{tabular}
$b^{54 \sim 57)}$ 。

表 5 錯体モノマーの見掛计の $Q, e$ 值

* 略㝵 : MMA メタクリル酸メチル, EA アクリル酸エチル, $\mathrm{AN}$ アクリロニトリル, MVP 2-メチル-5-ピニルピリジン $\mathrm{E}$ エチレン, $\mathrm{PD}$ pージォキセン, CEVE $\beta$-クロロエチルビニ ルエーテル, MAn 無水マレイン酸

iv. $Q, e$ 值よりみたモノマーの学独盏合悎 ここ では立体効果が無視できるような 1-置換および 1, 1-ジ 置換モノマーについて考えよう。表 4 からラジカル重合 に陉いてはモノマーの $Q$ 值が第 1 次因子乞して㗢き, $e$ 值は第 2 次因子として働くことがわかる（慗実 $e$ 值の差 が大きいモノマー間で， $Q$ 值が大きく異なる場合には共 重合性注きわめて悪い)。したがって，これまでにの心゙ てきたようにしてモノマーの $Q$ 值が予測されるが， $Q$ 值の大きい共役モノマーでは「モノマーとして高反応性 であるが，そのラジカルは低反応性である」といえる。 
このようなモノマーは一般に開始反応をおこしやすく， したがって誘導期などを生じにくく，かつ重合の再現性 が比較的よい。しかし，生長ラジカルは比較的安定で反 応性にそしく，したがって $k_{p}$ は小さく，生長反応の選 択性が大となる（副反応をおこしにくい）。

これに対してQ值の小さい非共役モノマーでは「モノ マーとして低反応性であるが，そのラジカルは高反応性 である」といえる。したがって，共役モノマーと逆に開 始反応をおこしにくく，重合の再現性にも乏しい。しか し生長ラジカルは高反応性であるために $k_{p}$ は大で，生 長反応の選択性にそしい。重合反応はポリマーラジカル の関与する多くの重合系中に存在する物質との競争反応 よりなっているので, ラジカルが高反応性であることは 生長以外の副反応（たとえば頭頭付加や種々の物質との 連鎖移動反応など）をおこしやすく，生成ポリマーの構 造にまで影響する。このようなちがいを共役モノマーで あるスチレンと，非共役モノマーである酶酸ビニルにつ いて表 6 にしめす。

表 6 スチレンと酢酸ビニルのラジカル重合 $\left(60^{\circ} \mathrm{C}\right)$

\begin{tabular}{|c|c|c|c|c|}
\hline$モ$ & ノ & $\nabla$ & スチレン & 酢酸ビニル \\
\hline \multicolumn{3}{|c|}{ 生長速度定数 $\left(l, \mathrm{~mol}^{-1}, \mathrm{sec}^{-1}\right)$} & 176 & 3700 \\
\hline \multicolumn{3}{|c|}{ 停止速度定数 $\left(l, \mathrm{~mol}^{-1}, \mathrm{sec}^{-1}\right)$} & $7.2 \times 10^{7}$ & $1.17 \times 10^{9}$ \\
\hline \multicolumn{3}{|c|}{ トルエンへの移動定数 } & $1.25 \times 10^{-5}$ & $2.1 \times 10^{-3}$ \\
\hline \multicolumn{3}{|c|}{ モノマーへの移動定数 } & $6.0 \times 10^{-6}$ & $2.5 \times 10^{-4}$ \\
\hline \multicolumn{3}{|c|}{ 生成ポリマーの枝分かれ } & $\sim 0$ & 多w \\
\hline \multicolumn{3}{|c|}{ 生成ポリマーの頭頭結合 } & $\sim 0$ & 約 $2 \mathrm{~mol} \%$ \\
\hline
\end{tabular}

次にモノマーの $e$ 值であるが, $Q$ 值の等しいようなモ ノマー間のラジカル共重合性を比較する上で重要であ る。しかし $e$ 值が正に大きい電子受容性モノマーと負に 大きい電子供与性モノマーの間では $Q$ 值に関係なく交 互共重合のおこる例が知られている (II. 4. ii 参照)。ま た，e值が正あるいは負に大きいモノマーではそれぞれ アニオンあるいはカチオン重合をおこしやすく，ラジカ ル重合性にそしいと考えられてきた。しかし $e$ が 2.1 と 正に大きい わめて弱、塩基（たとえば水）によって速やかにアニオ ン重合がおこるが，酢酸のような禁止剤の存在下では容 易にラジカル重合もおこる ${ }^{23,24)}$ 。また， $p$-置換スチレン およびメタクリル酸アルキルについても置換基の電子受 容性の増大する(したがってモ)マーの $e$ が正に大きく なる) ほど $k_{p}$ は増大する (図 2 および 3 )。したがって， 一般にモノマーの $e$ 值が正に増大するほどラジカル単独 重合性も増大寸るとみるべきであるう。

モノマーのラジカル単独重合性をきめる他の重要な因 子にその天井温度と破壊的連鎖移動効果がある。一般に
モノ置換モノマーの天井温度は $200^{\circ} \mathrm{C}$ 以上であるので, 通常の 重合条件では 問題とはならない。しかし 1,1-ジ 置換モノマーでは重合熱が小さいために天井温度が低く なるので，この点の注意が必要である。また，モノマー 中にベンジル型あるいはアリル型の活性水素原子をもつ 衤オレフィンやアリル系モノマーでは破壊的モノマー 連鎖移動がおこりやすく，高重合は見掛上進行しない。 このような反応のおこりやすさはモノマーの $Q$ 值と関 係し，アリル型活性水素原子を有する非共役モノマーで は生長ラジカルが高反応性であるためにおこりやすい。 たとえば酢酸イソプロペニル，酿酸アリル，塩化イソプ ロペニル，塩化アリル，プロピレン，イソブテンなどで はこのような理由でラジカル高重合をおこさない（ただ し，無水マレイン酸とは II. 4. ii でのベた理由で交互共 重合を行なら)。しかし共役型モノマーで $\alpha$ 一位にメチル 基をもつもの，たとえばメタクリル酸メチル，メタクリ ロニトリルでは生長ラジカルが比較的安定で $\alpha$ ーメル 基への移動反応は生長反応に比しておこりにくく, 高分 子量ポリマーを生成する。

\section{III. 置換基効果, ならびにそれからみた モノマーの構造と反応性}

1. 置換基効果 置換基だけがことなる一連の反 応の自由エネルギーにおよぼす構造の効果は古くより Hammett 式〔10〕で議論されてきた ${ }^{4}$ (6)。

$\log \left(k / k_{0}\right)=\rho \sigma$

ここで $k$ および $k_{0}$ は置換および無置換化合物の反応 の速度定数であり， $\rho$ は反応に固有の定数である。のは Hammett の置換基定数で, 置換安息香酸の解離定数上 り求められた值である。式〔10〕は多数のイオン反応に ついて成立し, 得られた $\rho$ 值から反応の遷移状態などに ついて有益な知見が与えられてきた。

しかし 1950 年頃より，ラジカル反応に Hammett 式を 適用する試みがふえるにつれて不成立の例が多くみられ るようになっだ ${ }^{98)}$ 。なかでも八ロゲン原子による水素 引き抜き反応のような親電子置換反応では式 [10]の $\sigma$

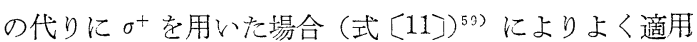
されることが指摘された ${ }^{9,60)}$ 。

$$
\log \left(k / k_{0}\right)=\rho \sigma^{+}
$$

ここで $\sigma^{+}$は置換フェニルジメチルカルビニルクロリ ドの $\mathrm{S}_{\mathrm{N}} 1$ 加溶媒分解から求められた置換基定数であ る。親電子置換反応においては遷移状態で形成されるカ ルボニウムイオンをより安定化させるような電子供与性 の置換基に対して $\sigma$ より大きい $\sigma^{+}$を見積ろうとするも のである (図 4 参照)。この試みは, 湯川, 都野 ${ }^{61)} に よ$ 
って式〔12〕のごとく展開させられた。

$\log \left(k / k_{0}\right)=\rho\left(\sigma+\gamma \Delta \sigma_{\mathrm{R}}{ }^{+}\right)$

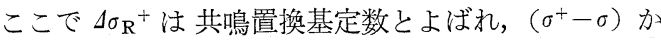
ら計算される。 $\gamma$ は共鳴安定化の程度を示す定数であ る。

しかし，求核的置換反応においては逆に式 [13〕の成 立を考慮すべきである。

$\log \left(k / k_{0}\right)=\rho \sigma^{-}$

ここで $\sigma^{-}$は置換フェノールやアニリンの反忘から求 められ，電子吸引性の置換基に対して 0 より大きい值を もつ。式〔13]の適用は古くWalling ら ${ }^{62)}$ にりポリス チリルラジカルに対する置換スチレンの反応に対して試 みられた。

低分子のラジカル反応における置換基効果は親電子反 応について多く試みられているが，求核的反応の例は少 ない。実験的なむづかしさもあるが，ポリマーラジカル の関与する反応ではこの点は有利であり，モノマーの置 換基をかえることによって両者の反応デー夕を豊富に取 り扱うことができる(III. 2 参照)。

反応位置が置換基と共役していないような一連の化合 物の反応においては，置換基の共鳴効果は重要となら す，むしら立体効果が極性効果とともに重要となる。こ のような場合の置換基効果の取り扱いに Taft の式 [14] がある ${ }^{63)}$ 。

$$
\log \left(k / k_{0}\right)=\rho^{*} \sigma^{*}+\delta E_{\mathrm{S}}
$$

ここで $\sigma$ および $E_{\mathrm{S}}$ はメチル置掺体を基準としてエ ステルの酸あるいはアルカリ加水分解より求められたそ

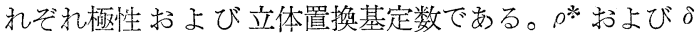
は極性および立体效果の程度を示す定数である。式〔14】 を用いてエステルモノマーおよびアルキル置換モノマー の反応性について解析されている (III.7 参照)。

2. Hammett 式の一般化 一連の反応における化 合物の反忘性が置換基の極性と共鳴効果の独立の寄与の 和として表わせると考えると，式〔15】が得られる ${ }^{58,64) 。 ~}$

$$
\log \left(k / k_{0}\right)=\rho \sigma+r E_{\mathrm{R}}
$$

ここで $\sigma$ および $E_{\mathrm{R}}$ はそれぞれ極性 (Hammett) およ び共鳴置換基定数であり， $\rho$ および $\gamma$ は極性および共鳴 の程度を表わす反応定数である。式〔11〕および〔13】と 式〔15〕の取り扱いのらがいを図4にしめす。前者では 反応性の差を新しい $\sigma$ で見積ろうとするのに対して，後 者では別のパラメータで表わそうとするものである。

式〔15]で，多くのイオン反応などでみられるごとく 置換基の極性効果の夕が重要なとき（したがって $r=0)$ には簡単に Hammett 式〔10]となる。また共鳴効果の みが重要である反応の場合 $(\rho=0)$ には式〔16】となる。

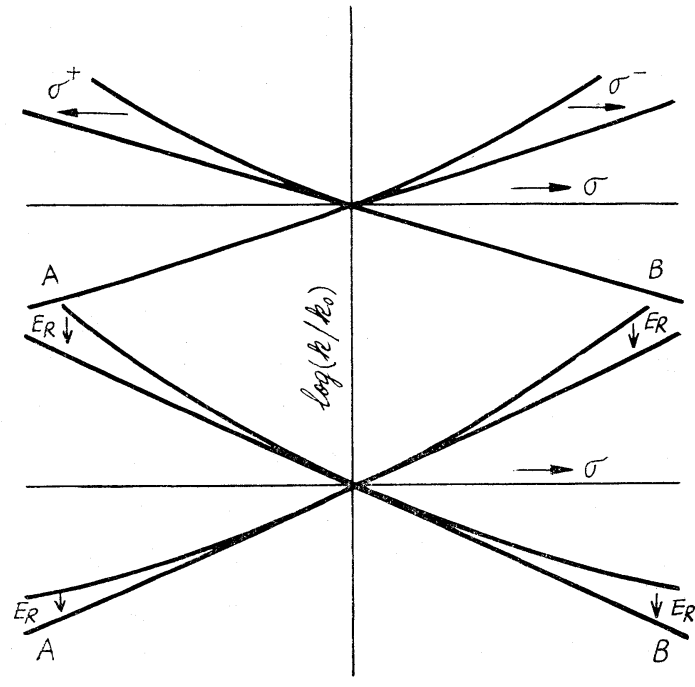

図 4 式〔11], [13]と式〔15]の取り扱いの比較 A 親核的反応, $B$ 親電子反応

$\log \left(k / k_{0}\right)=r E_{\mathrm{R}}$

したがって反応性が結合エネルギー効果で支配される ような反応から $E_{\mathrm{R}}$ を算出することができる。実際には ポリスチリルラジカルの 置換クメンへの連鎖移動反応 （水素引抜反応）を基準反応に選び，この反応の $\rho$ を $-0.7, r$ を 1.0 と仮定して求められている ${ }^{58,64)}$ 。この ようにして求められた $E_{\mathrm{R}}$ 值を表 7 にまとめる。 $E_{\mathrm{R}}$ 值 は $\left(\sigma^{+}-\sigma\right)$ および $\left(\sigma^{-}-\sigma\right)$, 川端 $\left.{ }^{15}\right) ら の \mathrm{Q}$ 值, Bamford $ら^{65)}$ の $\beta$ 值, 山田らの $\Delta \log \mathrm{Q}$ (表 2 ) とよい詨応関係 にあることが見出されている ${ }^{58)}$ 。

\begin{tabular}{|c|c|c|c|}
\hline 置 換 基 & $E_{\mathrm{R}}$ & 置 換 基 & $E_{\mathrm{R}}$ \\
\hline $\mathrm{H}$ & 0 & $p-F$ & 0.12 \\
\hline$m-\mathrm{CH}_{3}$ & 0 & $p-\mathrm{C}_{2} \mathrm{H}_{5} \mathrm{O}$ & 0.12 \\
\hline$p-\mathrm{CH}_{3}$ & 0.03 & $p-\mathrm{CF}_{3}$ & 0.13 \\
\hline$p-\mathrm{CH}_{3}$ & 0.03 & $p-\mathrm{CH}_{3} \mathrm{~S}$ & 0.13 \\
\hline$p-\mathrm{C}_{2} \mathrm{H}_{5}$ & 0.03 & $p-\mathrm{COOC}_{2} \mathrm{H}_{5}$ & 0.13 \\
\hline$p-i-\mathrm{C}_{3} \mathrm{H}_{7}$ & 0.03 & $p-\mathrm{NHCOCH}_{3}$ & 0.14 \\
\hline$p-t-\mathrm{C}_{4} \mathrm{H}_{9}$ & 0.03 & $p-\mathrm{OH}$ & 0.14 \\
\hline$p-\left(\mathrm{CH}_{3}\right)_{8} \mathrm{Si}$ & 0.03 & $p-\mathrm{COOCH}_{3}$ & 0.15 \\
\hline$m-\mathrm{CH}_{3} \mathrm{O}$ & 0.05 & $m-\mathrm{CN}$ & 0.18 \\
\hline$m-\mathrm{Cl}$ & 0.08 & $p-\mathrm{NH}_{2}$ & 0.19 \\
\hline$m-\mathrm{Br}$ & 0.09 & $p-\left(\mathrm{CH}_{3}\right)_{2} \mathrm{~N}$ & 0.24 \\
\hline$p-\mathrm{Cl}$ & 0.10 & $p-\mathrm{SO}_{2} \mathrm{NH}_{2}$ & 0.25 \\
\hline$p-\mathrm{CH}_{3} \mathrm{O}$ & 0.11 & $p-\mathrm{SO}_{2} \mathrm{CH}_{3}$ & 0.25 \\
\hline$p-\left(\mathrm{CH}_{3} \mathrm{O}\right)_{3} \mathrm{Si}$ & 0.11 & $p-\mathrm{CN}$ & 0.24 \\
\hline$p-\mathrm{Br}$ & 0.12 & $m-\mathrm{NO}_{2}$ & 0.35 \\
\hline$p-\mathrm{I}$ & 0.12 & $p-\mathrm{NO}$ & 0.41 \\
\hline
\end{tabular}

表 7 置換基の $E_{\mathrm{R}}$ 值*

* 他のパラメー夕との相関関係 $〔 E_{\mathrm{R}}=0.76\left(\sigma^{-}-\sigma\right)$ または $\left.0.22\left(\sigma^{+}-\sigma\right)\right]$ より求めた值む含む

3. 共鳴効果を加味した他の Hammett 式, ならび 
にそれらと $\boldsymbol{Q}, \boldsymbol{e}$ 論との相関性 右田, 島村ら ${ }^{66}$ は置 換フェニルラジカルによる置換ベンゼンの $p$-位アリー ル化に対して式〔17〕を，また井本，木下ら ${ }^{67}$ は $p$-置換 スチレン相互間のラジカル共重合より.式〔18〕を提出し ている。

$$
\begin{aligned}
& \log \left(k / k_{0}\right)=\rho \sigma+\tau_{p} \\
& \log \left(k / k_{0}\right)=\rho \sigma+\mathrm{R}
\end{aligned}
$$

ここで $\tau_{p}$ および R はいずれも相当する反応に対する 共鳴置換基定数であり, 式〔15]の $E_{\mathrm{R}}$ と相関関係があ る。最大のちがいは反応定数 $(r)$ が含まれているかいな いかである。

式〔15】㧍よび $Q, e$ 論の基本式 $[2]$ を書き直すと式 [19]および〔20】が得られる。これらならびに Bamford $ら^{65)}$ の式〔21】を比較するといずれも同形であり，また 式〔17〕および〔18】とも同形であることがわかる。

$$
\begin{aligned}
& \log k=\log k_{0}+\rho \sigma+r E_{\mathrm{R}} \\
& \log k_{12}=\log P_{1}-e_{1} e_{2}+\log Q_{2} . \\
& \log k_{\mathrm{S}}=\log k_{\mathrm{T}}+\alpha \sigma+\beta \ldots \ldots \ldots \ldots . .
\end{aligned}
$$

すなわち，、ずれも右辺第 1 項は攻撃ラジカルの基準 の反応性, 第 2 項は攻撃ラジカルと被反応物の極性項, 第 3 項は被反応物の共鳴項である。お互い相関性のあ ることは明らかである。

4. 式〔15〕から置換基効果としてのモノマーの極性 と共鳴効果の評価 式〔15]を移項すると式 [22〕〜 〔24】が誘導される。

$$
\begin{aligned}
& \log \left(k / k_{0}\right)-\gamma E_{\mathrm{R}}=\rho \sigma \\
& \log \left(k / k_{0}\right)-\rho \sigma=r E_{\mathrm{R}} \\
& \log \left(k / k_{0}\right) / \sigma=\rho+\gamma\left(E_{\mathrm{R}} / \sigma\right)
\end{aligned}
$$

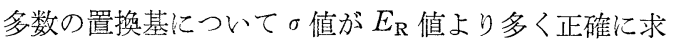
放机ているので, 適用に際しては式〔22〕の形で用い る方が好都合である。すなわち, 式〔22〕の左辺が右辺 の $\sigma$ と直線関係を満足するようにてを選ぶことによっ

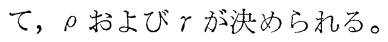

このようにして式〔15〕はほとんどすべてのイオン反 応ならびにラジカル反応に適用しらることが見出され た。詳細は別稿58, 68) にゆづり,ここで汶モノマーの反応 性に適用した場合についてのべる。井本, 木下らは $p$-置 換スチレンのラジカル単独重合 ${ }^{43}$ ならびにこれらモノマ 一相互間の共重合 ${ }^{67}$ における置換基効果について研究し ている。前者の結果は II. 4. ii でのべた。相互共重合に おける反応は次式で表わされる。

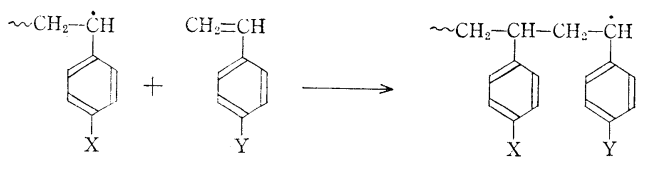

攻撃ラジカルを一定（X を固定）して反応する $p$-置 換スチレンの置換基効果はいずれの X に対しても通常 の Hammett 式〔10〕に従わない（図 5)。このことは Walling $5^{62)}$ の結果とも一致する。この反忘代式 〔15】 を適用すると表 8 に示した $\rho$ および $\gamma$ で直線関係が成 立した。同様な結果は $m$-置換ポリスチリルラジカルに 対するp-置換スチレンの反応に扔ける置換基効果につ

\begin{tabular}{|c|c|c|c|}
\hline 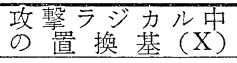 & $\rho$ & $\gamma$ & $\mathrm{S}$ \\
\hline$p-\mathrm{CH}_{3} \mathrm{O}$ & 0.85 & 1.5 & 0.027 \\
\hline $\mathrm{H}$ & 0.60 & 1.4 & 0.029 \\
\hline$p-\mathrm{Cl}$ & 0.15 & 1.5 & 0.025 \\
\hline$p-\mathrm{CN}$ & -0.25 & 0.7 & 0.020 \\
\hline
\end{tabular}
いても認められたが69)，p-あるいは $m$-置換ポリスチリ

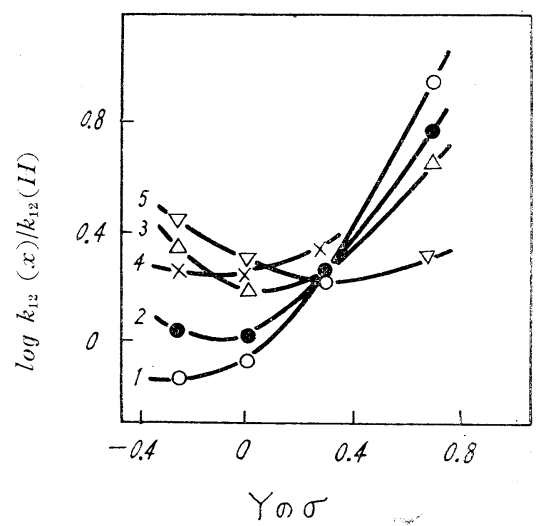

図 $5 p$-X-置換ポリスチリルラジカルの $p$ - $Y$-置換ス チレンヘの付加反応における $\mathrm{Y}$ の置換基効果

1. $\mathrm{X}=\mathrm{CH}_{3} \mathrm{O}, 2 . \mathrm{X}=\mathrm{H}$, 3. $\mathrm{X}=\mathrm{Cl}, 4 . \mathrm{X}=\mathrm{Br}, 5 . \mathrm{X}=\mathrm{CN}$

交 $8 p$-置換ポリスチリルラジカルに対する $p$-置換 スチレンの反応性に式 [15]の通用

ルラジカルに対する $m$-置換スチレンの反応については $r=0$, すなわち通常の Hammett 式〔10]が成立した ${ }^{70)}$ 。 このことは生成ラジカルの置換基による共鳴安定化が重 要であることを物語っている。表 7 から，rはp-CN 置 換体妾除いて $r$ は約 1.5 の值であり, $\rho$ は攻撃ラジカル 中の置換基の極性に依存して変化する。

一方，p-置換モノマーを一定 ( $\mathrm{Y}$ を固定) として攻撃 ラジカル中の置換基を変化した場合の置換基効果汇図 6 に示すように通常の Hammett 式（すなわち式〔15〕で $r=0)$ が成立する。 0 值注 9 のように $p$-置換スチレ ンの極性に刘応して変化する。このように攻撃ラジカル 侧の置換基効果では共鳴項海視でき, 被反応こノマー 側の置換基効果で 重要となることは p-置換ポリスチリ ルラジカルに対する置換クメンの連鎖移動反応について も認められている 


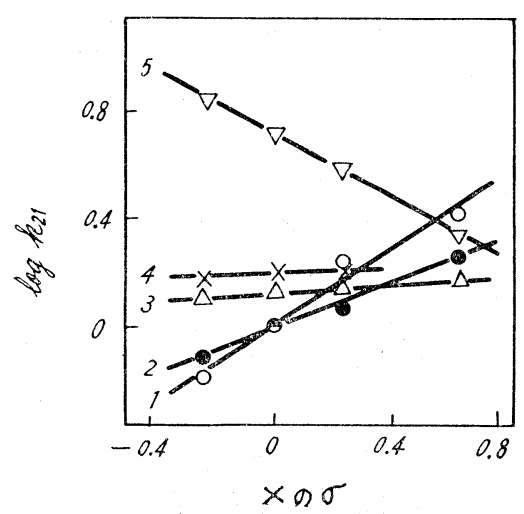

図 $6 p$-X-置換ポリスチリルラジカルの $p$ - $\mathrm{Y}$-置換ス チレンへの付加反応における $\mathrm{X}$ の置換基効果

1. $\mathrm{Y}=\mathrm{CH}_{3} \mathrm{O}, 2$. $\mathrm{Y}=\mathrm{H}$, 3. $\mathrm{Y}=\mathrm{Cl}$, 4. $\mathrm{Y}=\mathrm{Br}, 5 . \mathrm{Y}=\mathrm{CN}$

表 $9 p$-置換スチレンに対する $p$-置換ポリスチリル ラジカルの反応性に式 [15]の適用

\begin{tabular}{|c|c|c|}
\hline 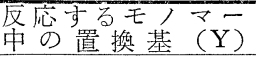 & $\rho$ & $\gamma$ \\
\hline$p-\mathrm{CH}_{3} \mathrm{O}$ & 0.67 & 0 \\
\hline $\mathrm{H}$ & 0.49 & 0 \\
\hline$p-\mathrm{Cl}$ & 0.05 & 0 \\
\hline$p-\mathrm{Br}$ & 0.10 & 0 \\
\hline$p-\mathrm{CN}$ & -0.56 & 0 \\
\hline
\end{tabular}

上記反応の遷移状態は次式のごとく表わされる。

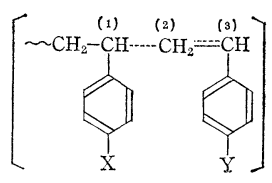

上述の結果から遷移状態に扔ける X および $\mathrm{Y}$ 置換基 の極性効果は重要に㗢くが，Xの共鳴効果は関係せずに Yの共鳴効果が重要であることがわかる。井本，木下 ら ${ }^{67)}$ は 遷移状態で反応する 置換スチレンの 2-位炭素に およぼす $\mathrm{X}$ および $\mathrm{Y}$ 置換基の極性効果が等しいと仮定 して，図 5 およびの 6 プロットを重叔合せてその反応性 の差より共鳴置換基定数 $(\mathrm{R})$ を算出している。さらに $m$-置換スチレン相互間の共重合結界 ${ }^{69)}$ との比較より, 遷 移状態では $\mathrm{C}_{1}-\mathrm{C}_{2}$ の距離が $\mathrm{C}_{2}-\mathrm{C}_{3}$ より犬であるため $\mathrm{Y}$ の極性寄与が X のそれより大きい ( 2 にして 0.3 ) 結果 を得ている。これにもとづいて $\mathrm{R}$ 值の修正も行なわれ ている。

フェニル基上の置換基が反応する二重結合と共役して いる他のモノマーとして $p$-置換フェニルビニルケトン があり，この場合にもモノマーの反応性は式〔15】で適 用されることが報告されている ${ }^{72)}$ 。直接共役していない 置換フェニルビニルスルフィド ${ }^{73)}$, フェニルチオールメ
タクリレート ${ }^{74}$ 抢よび安息香酸ビニル ${ }^{75}$ )の反応性は通常 の Hammett 式〔10〕で成立する。ただしポリスチリル ラジカルに対する置換フェニルメタクリレートの反応で は式〔15〕で $\rho=0.21, r=1.0$ で成立する ${ }^{76)}$ 。

5. モノマーの反応性への式 〔15〕の拡張の試み 式〔10〕の Hammett の置換基定数认置換安息香酸の解 離定数から求められており, 式〔15〕でもそれを採用し ている。したがって置換基がフェニル基安通して反応点 に効果が伝達されるので, ビニルモノマーのようにフェ ニル基を介せずに置換基が結合したものの反応性に対し ては式〔15〕をそのまま用いることはできない。このよ らな場合の取り扱いを考えてみる77。

いま，ポリスチリルラジカルが核置換卜ルエンから側 鎖メチル基の水素引き抜き反応に対して式〔15】を適用 すると，実験的に式〔25〕が成立する ${ }^{78)}$ 。

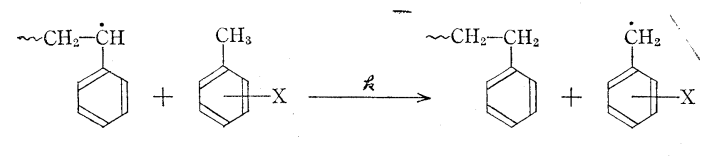

$\log \left(k / k_{0}\right)=0.3 \sigma+0.6 E_{\mathrm{R}}$

つぎに, 同じラジカルが側鎖置換トルエンからの水素 引き抜き反応を考える。

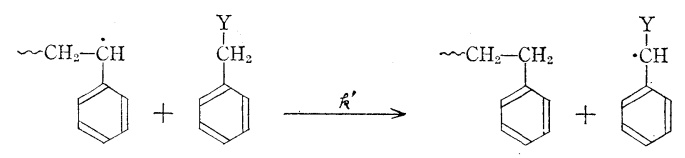

側鎖置換基 $(\mathrm{Y})$ は反応位置に直接結合しているので, 反忘性に打よぼす $\mathrm{Y}$ の効果注核置換基 $(\mathrm{X})$ のそれと異 なるはずである。Yの極性効果はベンゼン核の伝達倸数 (0.303) を考虑してXの $\mathrm{X}$ 值を用いることができる。 もちろん無置換トルエンの反応を基準に用いるために, 両置換体で反応に関与しうる水素原子の補正が必要であ る。このようにして側鎖置換トルエンの反応性法式〔26】 で示される。

$$
\log \left(k^{\prime} / k_{0}{ }^{\prime}\right)=0.3(3.3 \sigma)+0.6 E_{\mathrm{R}}{ }^{\prime}
$$

ここで, $E_{\mathrm{R}}{ }^{\prime}$ は側鎖置換基の共鳴置換基定数である。 むし $E_{\mathrm{R}}{ }^{\prime}$ が $E_{\mathrm{R}}$ とかりに等しければ両置換卜ルエンの 反応性は $\sigma$ で表わされることが期待される。実験で得ら れたプロットを図 7 亿しめす ${ }^{77) 。 ~}$

図 7 から明らかに側鎖置換トルエンの反态に対しては 直線関係は成立せず，上向きの曲線となる。同様な結果は ポリメタクリル酸メチル捛よびtーブトキシラジカルの反 応についても認められた。したがって側鎖置換基に対し ては核置換基よりも大きい別の共鳴置換基効果芝考慮す る必要のあることがわかる。このこと注両反応で生成す 


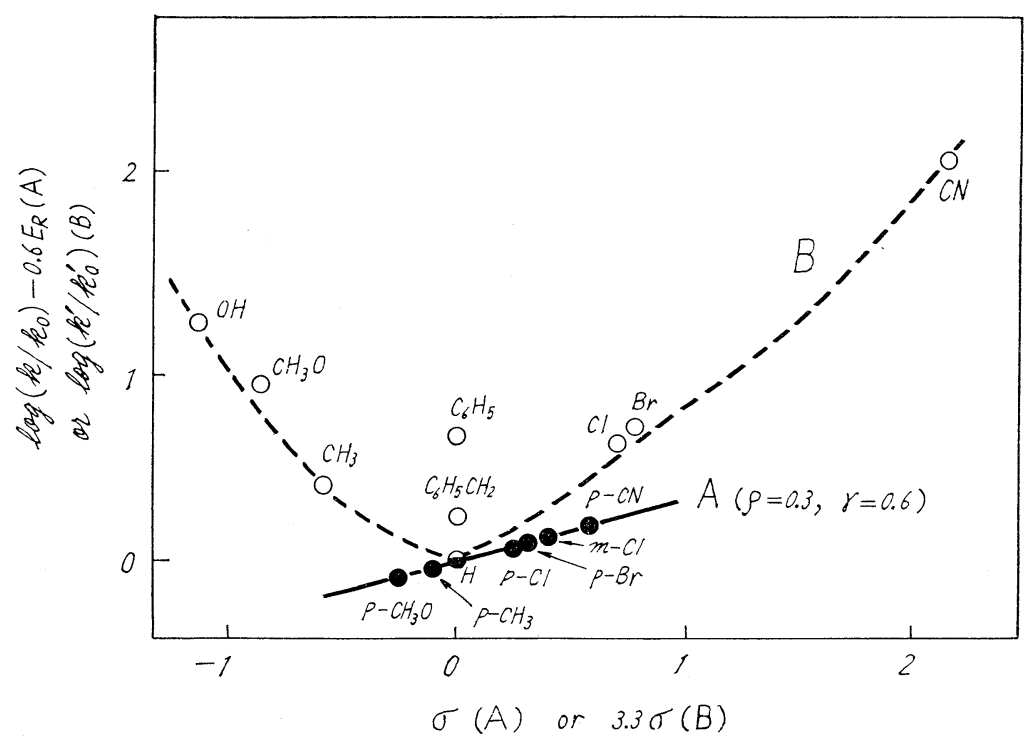

図 7 ポリスチリルラジカルに対する核置換トルエン (A) および側鎖置換 トルエン (B) の連鎖移動反応に式 [25]，〔26]の適用
るラジカルの構造を比較しても明 らかであり，また II. 2 でのべた $\alpha$-置換アクリル酸エステルおよび アクリロニトリルの $Q$ 值が大きく なることからも理解される（表 1

表 10 側鎖置換基定数 $\left(E_{\mathrm{R}}{ }^{\prime}\right)^{*}$

\begin{tabular}{|c|c|}
\hline 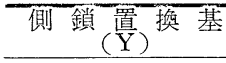 & $E_{\mathrm{R}}^{\prime}$ \\
\hline $\mathrm{OH}$ & 1.60 \\
\hline $\mathrm{OC}_{6} \mathrm{H}_{5}$ & 1.40 \\
\hline $\mathrm{OCH}_{3}$ & 1.15 \\
\hline $\mathrm{CH}_{3}$ & 0.50 \\
\hline $\mathrm{C}_{6} \mathrm{H}_{5}$ & 0.65 \\
\hline $\mathrm{H}$ & 0 \\
\hline $\mathrm{Cl}$ & 0.65 \\
\hline $\mathrm{Br}$ & 0.75 \\
\hline $\mathrm{CN}$ & 1.45 \\
\hline $\mathrm{CH}_{2} \mathrm{C}_{6} \mathrm{H}_{5}$ & 0.20 \\
\hline
\end{tabular}

*ポリステリルおよびポリメタクリル酸メ チルラジカルの側鎖置換トルエンへの連 鎖移動反応から求めた值の平均值

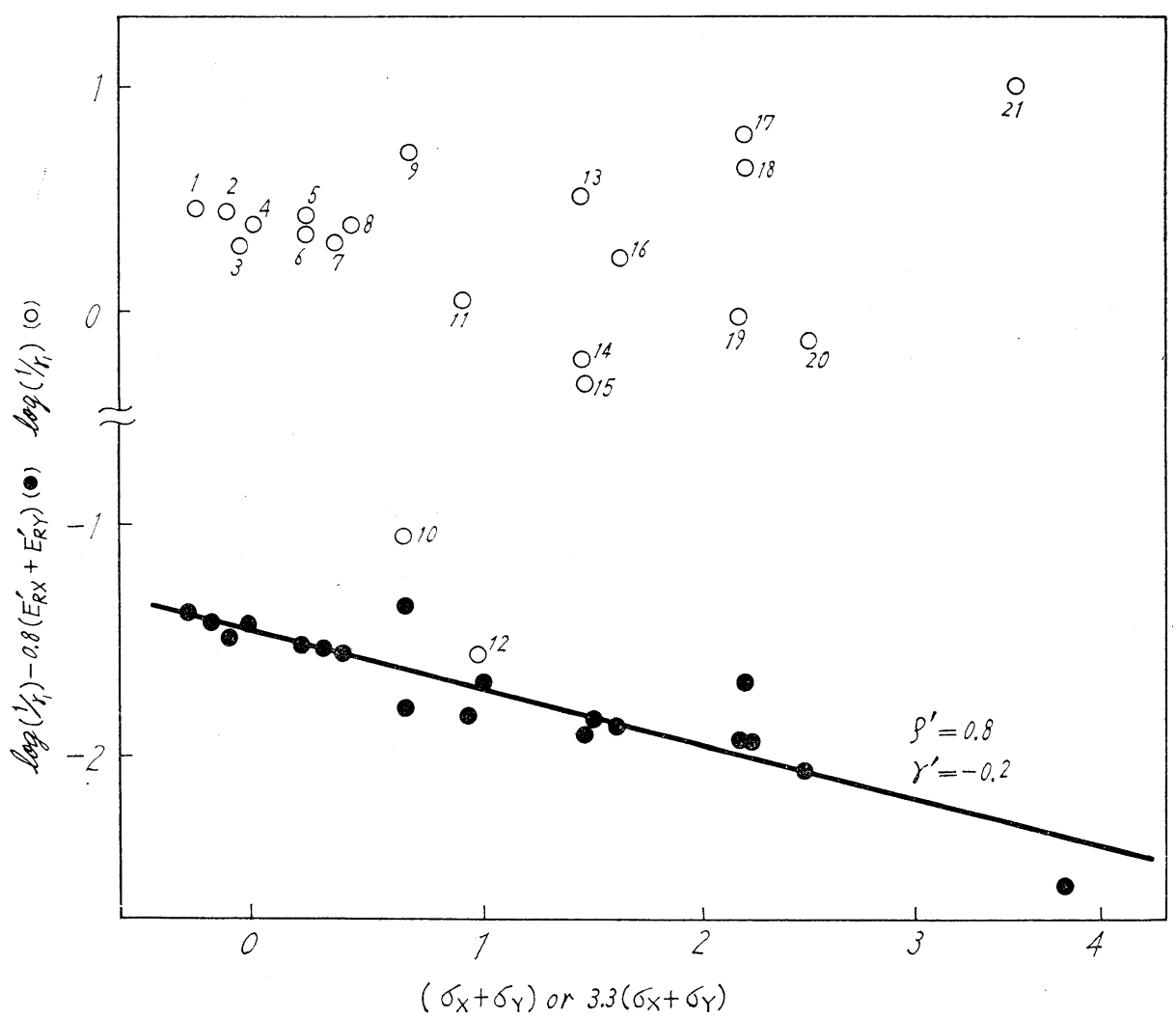

図 8 ポリメタクリル酸メチルラジカルのモノ置換およびジ置換モノマーの反応性に式 [27]の 適用, 番号注次の置換基をもつモノマーを示す

1. $\mathrm{X}=\mathrm{H}, \mathrm{Y}=p-\mathrm{CH}_{3} \mathrm{OC}_{6} \mathrm{H}_{4}$, 2. $\mathrm{X}=\mathrm{H}, \mathrm{Y}=p-\mathrm{CH}_{3} \mathrm{C}_{6} \mathrm{H}_{4}$, 3. $\mathrm{X}=\mathrm{H}, \mathrm{Y}=m-\mathrm{CH}_{3} \mathrm{C}_{6} \mathrm{H}_{4}, 4 . \mathrm{X}=\mathrm{H}, \mathrm{Y}=\mathrm{C}_{6} \mathrm{H}_{5}, 5 . \mathrm{X}=\mathrm{H}, \mathrm{Y}=p-\mathrm{BrC}_{6} \mathrm{H}_{4}, 6 . \mathrm{X}=$ $\mathrm{H}, \mathrm{Y}=p-\mathrm{ClC}_{6} \mathrm{H}_{4}, 7 . \mathrm{X}=\mathrm{H}, \mathrm{Y}=m-\mathrm{ClC}_{6} \mathrm{H}_{4}, 8 . \mathrm{X}=\mathrm{H}, \mathrm{Y}=m-\mathrm{BrC}_{6} \mathrm{H}_{4}, 9 . \mathrm{X}=\mathrm{H}, \mathrm{Y}=p-\mathrm{CNC}_{6} \mathrm{H}_{4}, 10 . \mathrm{X}=\mathrm{H}, \mathrm{Y}=\mathrm{Cl}, 11 . \mathrm{X}=\mathrm{CH}, \mathrm{Y}=$ $\mathrm{COOCH}_{3}, 12 . \mathrm{X}=\mathrm{H}, \mathrm{Y}=\mathrm{OCOCH}_{3}, 13 . \mathrm{X}=\mathrm{COOCH}_{3}, \mathrm{Y}=\mathrm{C}_{6} \mathrm{H}_{5}, 14 . \mathrm{X}=\mathrm{H}, \mathrm{Y}=\mathrm{COOCH}_{3} 15 . \mathrm{X}=\mathrm{Cl}, \mathrm{Y}=\mathrm{Cl}, 16 . \mathrm{X}=\mathrm{CH}, \mathrm{Y}=\mathrm{CN}$, 17. $\mathrm{X}=\mathrm{Cl}, \mathrm{Y}=\mathrm{COOCH}_{3}, 18 . \mathrm{X}=\mathrm{Br}, \mathrm{Y}=\mathrm{COOCH}_{3}, 19 . \mathrm{X}=\mathrm{H}, \mathrm{Y}=\mathrm{CN}, 20 . \mathrm{X}=\mathrm{OCOCH}_{3}, \mathrm{Y}=\mathrm{COOC}_{2} \mathrm{H}_{5}, 21 . \mathrm{X}=\mathrm{CN}, \mathrm{Y}=\mathrm{COOCH}_{3}$. 
参照)。そこで $\mathrm{Y}$ の $E_{\mathrm{R}}{ }^{\prime}$ を求めるために図 7 の核置換 トルエンについての直線から側鎖置換トルエンについて の值の差をとると表 10 のごとく得られる。 $E_{\mathrm{R}}{ }^{\prime}$ は $E_{\mathrm{R}}$ 上りを約10 倍大きいことがわかる。

このようにして，ビニルモノマーの反応性におよぼす 置換基の効果は式〔27〕で表わされる。

$$
\log \left(k / k_{0}\right)=\rho^{\prime}(3.3 \sigma)+r^{\prime} E_{\mathrm{R}}{ }^{\prime}
$$

いま文献で報告されているメタクリル酸メチル $\left(\mathrm{M}_{1}\right)$ と種々のモノマーの共重合パラメータからポリメタク リル酸メチルラジカルに対するモノマーの相対反忘性 $\left(1 / r_{1}\right)$ をプロットすると図 8 が得られる。図から共鳴効 果を考慮しない場合 (白丸) には一定の関係はみられな いが， $\sigma$ と同様に $E_{\mathrm{R}}{ }^{\prime}$ に加成性があるとして式〔27】を 用いた場合 (黑丸) には $\rho^{\prime}=-0.28, \gamma^{\prime}=0.8$ として比 較的良好な直線関係の成立することがわかる。ただしプ ロットに当っては核置換 スチレン誘導体については式 〔15]を用い，また $E_{\mathrm{R}}{ }^{\prime}$ が未知の置換モノマーでは近似 的に $E_{\mathrm{R}}{ }^{\prime}=10 E_{\mathrm{R}}$ と仮定して用いた。図8から得られた ○值が負であることはポリメタクリル酸メチルラジカル の親電子性が大きい事実と一致する。同様な結果は他の ポリマーラジカルに対するモノマーの反応性に対しても 認的られた。

6. 1,1-ジ置換モノマーの反忩性 さきにのべたよ うに $\alpha$-置換アクリル酸エステルおよびアクリロニトリ ルの $Q, e$ 值は式〔5]〜[8] で表わされる。表 1 に示し た共重合データからポリスチリルラジカルに対するこれ ら $\alpha$-置換モノマーの相刘反忘性を式〔10]にしたがって ひ-置換基の $\sigma$ でプロットすると直線関係は得られず，共 鳴置換基定数 $(\Delta \log Q)$ （表 2 ）を含む式〔28】でプロッ 卜すると直線関係 $(\rho=0.83, \mathrm{~A}=1)$ の得られることが 見出された。

$$
\log \left(k / k_{0}\right)=\rho \sigma+\mathrm{A} \Delta \log Q
$$

ここで $\mathrm{A}$ は反応定数である。関連モノマーについて の結果を表 11 によと市。

\begin{tabular}{|c|c|c|c|c|}
\hline 攻揧 ラジ， & ر - & $\rho$ & A & 文献 \\
\hline 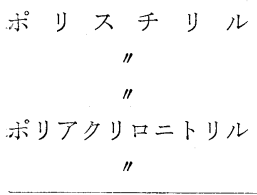 & $\begin{array}{l}\alpha \text {-置換 } \\
\alpha \text {-置換 }\end{array}$ & $\begin{array}{l}0.83 \\
0.83 \\
0.83\end{array}$ & $\begin{array}{l}1.0 \\
1.0 \\
1.0 \\
1.7 \\
1.7\end{array}$ & $\begin{array}{l}25 \\
25 \\
79 \\
79 \\
79\end{array}$ \\
\hline
\end{tabular}

表 11 1,1-ジ置換モノマーの反応性に対する式 [28]の適用

\section{Taft 式〔14〕による極性および立体効果の評価}

これまで反応位置が直接あるいはフェニル基を通して 置換基と共役しているようなモノマーの反応性功置換基 の極性と共鳴効果の寄与の和として表わされることをの
べてきた。置換基が反応位置と共役していないようなモ ノマーでは共鳴効果は無視でき, 極性効果のみで反応性 と関係づけることができる。この場合，反応位置と置換 基の間に存在する原子あるいはグループのために置換基 のI効果の伝達は著るしく減殺されるので, その效果 ( $\rho$ 值) は小さくなる。これに加えて置換基の結合位置 によってはその立体効果が重要となる。このような一連 のモノマーの置換基效果は Taft 式〔14〕で取り扱われ $3^{63)}$ 。

i. エステルモノマーの反応性におよに゙すアルキル基 の効果 メタクリル酸アルキルの生長速度定数 $\left(k_{p}\right)$ と エステルアルキル基の構造の関係は Burnett $ら^{80)}$ によっ て研究され， $n$-ブチル基まで筒高さが増しても $k_{p}$ は変 化しないことが示されてきた。横田ら ${ }^{44)}$ は 10 種のメタ クリル酸アルキルについて $k_{p}$ を測定し, $\log k_{p}$ をアル キル基の $\sigma^{*}$ でプロットすると， $\beta$-シクロヘキシルエチ ルおよびベンジルエステルを除いて良好な直線関係の成 立することを見出している (図 3 参照)。

Taft の式〔14】を用いてメタクリル酸アルキルのラシ カル反応性の解析は大津, 伊藤 ${ }^{81,82)}$ らによって試みられ, ポリスチリルラジカルの攻撃に対して $\rho^{*}=0.33, \delta=0$ として良好な直線関係が成立した（図 9)。このことは

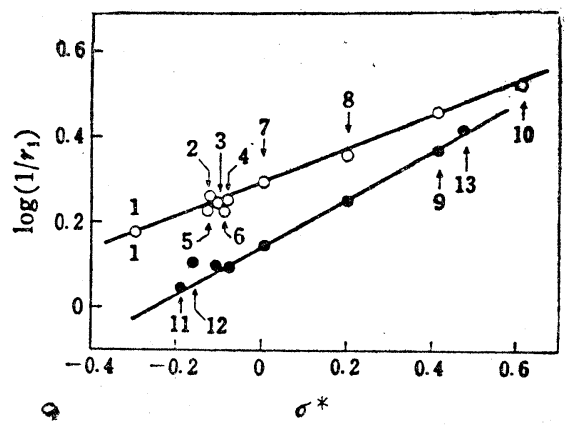

図 9 ポリスチリルラジカルに対するメタクリル酸 アルキルおよびアクリル酸アルキルの反応性 $\log \left(1 / \gamma_{1}\right)$ と $\sigma^{*}$ の関係

1. $t-\mathrm{C}_{4} \mathrm{H}_{9}, 2 . \mathrm{C}_{6} \mathrm{H}_{11}$, 3. $i-\mathrm{C}_{4} \mathrm{H}_{9}, 4 . \mathrm{C}_{2} \mathrm{H}_{5}$, 5. $n-\mathrm{C}_{4} \mathrm{H}_{9}$ 6. $n-\mathrm{C}_{3} \mathrm{H}_{7}, 7 . \mathrm{CH}_{3}, 8 . \mathrm{C}_{6} \mathrm{H}_{5} \mathrm{CH}_{2}, 9 . \mathrm{ClCH}_{2} \mathrm{CH}_{2}, 10$.

$\mathrm{C}_{6} \mathrm{H}_{5}, 11 . s-\mathrm{C}_{4} \mathrm{H}_{9}, 12 . i-\mathrm{C}_{3} \mathrm{H}_{7}, 13 . \mathrm{CNCH}_{2} \mathrm{CH}_{2}$ 一ー: メタクリレート, 一一:アクリレート

メタクリル酸アルキルのラジカルに対する反応性はエス テルアルキル基の極性効果に支配され，その立体効果に 関係しないことを示している。同様な結果は攻撃ラジカ ル44)としてポリメタクリル酸メチルラジカルおよびポリ メタクル酸- $\beta$-クロルエチルラジカル22) 党用いた場合に も観察された。得られた $\rho^{*}$ 值を表 12 によめるが, 。*はいずれも小さく攻撃ラジカルの極性に関係して変化 する。 
表 12 エステルモノマーの反応性に Taft 式〔14〕の適用

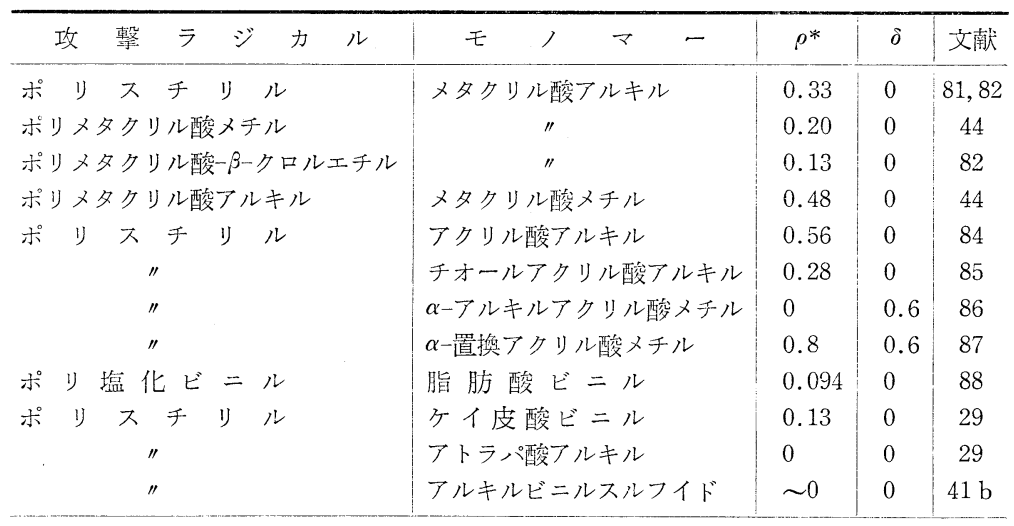

メタクリル酸アルキル中のアルキル基々反応する二重 結合と離孔ており, 分子模型からもその立体効果の作用 しないことは明らかである。スチレンとの共重合データ から求めたメタクリル酸アルキルの $Q, e$ 值はアルキル 基の $\sigma^{*}$ と右上りの直線で示される。このことから電子 供与性のアルキル基吕導入されることによって，メタク リル酸エステルのカルボニル基の分極は増大し，反応す る二重結合との共役が低下するために反応性が低下する と考えられる ${ }^{82)}$ このことは紫外吸收スペクトルからも 支持される ${ }^{83)}$ 。

横田ら ${ }^{44}$ はメタクリル酸メチルに対するポリメタクリ゙ ル酸アルキルラジカルの反応性におよぼすアルキル基の 効果について研究している。<smiles>[R]OC(=O)C(C)(CC)CCCCC(C)(CC(C)C(=O)OC)C(=O)OC</smiles>

この場合, 反応性を式〔27〕にしたがってラジカル側 のアルキル基の $\sigma$ 落でプロトすると， $\rho^{*}=0.48$ で直線 で表わされる。これに対してポリメタクリル酸メチルラ ジカルに対するメタクリル酸アルキルのプロットでは, $\rho^{*}=0.2$ の直線関係が成立している。これら反応の遷移 状態注,

$$
\left[\begin{array}{cc}
\mathrm{CH}_{3} & \mathrm{CH}_{3} \\
\sim \mathrm{C} & \mathrm{C} \\
\mathrm{C}=\mathrm{CH} & \mathrm{C} \\
\mathrm{C}=\mathrm{O} & \mathrm{C}=\mathrm{O} \\
\mathrm{OR} & \mathrm{OR}
\end{array}\right]
$$

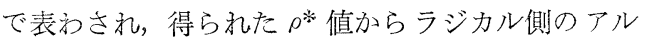
キル基の極性効果がモノマー側よりも約 2.5 倍大き

く働いていることがわかる。

その他ポリマーラジカルに対するアクリル酸アル キ ${ }^{84)}$ ，チオールアクリル酸アルキル85)，ケイ皮酸 アルキル29)，脂肪酸ビニル ${ }^{88)}$ の反応性に対しても式
〔14】の適用から，アルキル基の極 性効果のみが重要であることが認め られた (表 12 参照)。

\section{ii. $\boldsymbol{\alpha}$-アルキル置換アクリル酸メ} チルの反応性におよばす $\boldsymbol{\alpha}$ チアルキ ル基の効果 鶴田, 近西 ${ }^{86)}$ は種々 の๙ーアルキルアクリル酸メチルと スチレンのラジカル共重合より，こ 礼らモノマーの䄄対反応性を式〔 14 でプロットしたところ， $\rho^{*}=0, \quad \delta=$ 0.6 で直線関係の成立することを見 出した。この結果から, 反応性はいー アルキル基の極性效果に関係せず， 立体效果に依存していることがわかる。この場合の アルキル基はエステルアルキル基と異なって反応する三 重結合と直接結合しており，共鳴ならびに極性効果が小 さいアルキル基の置換ではその立体効果が反応性を支配 すると考えられる。

Cameron ら ${ }^{87)}$ は上記の結果に極性效果の大きいい-置 換基（たとえば $\mathrm{Cl}$ あるいは $\mathrm{Br}$ ) のデータを加味して式 [14]の再プロットを行ない， $\rho^{*}=0.8, \delta=0.6$ で良好な 直線関係の成立すること裳報告している。しかし，プロ ットをみるとフェニル基はいまだこの直線から偏異して おり，このような場合には共鳴効果の補正も必要である ら。

iii. $\alpha$ および $\boldsymbol{\beta}$-アルキルスチレンの反応性におよぼ すアルキル基の効果 安福 ${ }^{22}$ らはアクリロニトリルと種 々の $\alpha$-および $\beta$ ーアルキルスチレンのラジカル共重合 を行ない，相対反忘性を比較した。その結果を表 13 に しめす。これから ßーアルキルスチレンよりも約 10２0 倍高店応性であり， $\sigma$-に比して $\beta$-アルキル基の立体効果の大きいことがわ かる。また， $\beta$-アルキル スチレンでは trans 体の方が 3 〜 倍高反応性であることがわかる。

表 13 ポリアクリロニトリルラジカルに対する $\alpha$-および $\beta$-置換アルキルスチレン (RSt) の反応性 ${ }^{31}$

\begin{tabular}{l|c|c|c|c}
\hline \multicolumn{1}{c|}{$\mathrm{R}$} & $\alpha-\mathrm{RSt}$ & trans- $\beta-\mathrm{RSt}$ & cis- $\beta$-RSt & $\alpha$-RSt/trans- $\beta$-RSt \\
\hline $\mathrm{H}$ & $\sim 33$ & $\sim 33$ & - & 1 \\
$\mathrm{CH}_{3}$ & 33 & 1.75 & 0.62 & 19 \\
$\mathrm{C}_{2} \mathrm{H}_{5}$ & 13 & 1.02 & 0.39 & 13 \\
$n-\mathrm{C}_{3} \mathrm{H}_{7}$ & 14 & 0.96 & 0.33 & 15 \\
$n-\mathrm{C}_{4} \mathrm{H}_{9}$ & 13 & 0.92 & 0.18 & 14 \\
$i-\mathrm{C}_{3} \mathrm{H}_{7}$ & 5.6 & 0.30 & 0.06 & 19 \\
$s-\mathrm{C}_{4} \mathrm{H}_{3}$ & 3.3 & 0.16 & 0.04 & 21 \\
$t-\mathrm{C}_{4} \mathrm{H}_{9}$ & 0.5 & 0.05 & - & 10 \\
& & & &
\end{tabular}




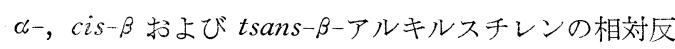
応性を式〔14〕のアルキル基の $E_{\mathrm{S}}$ 值でプロットすると かなり良好な直線関係が成立し，立体効果が支配因子と なっていることがわかる。さらに反応点のとなりのメチ レン基の超共役効果を分離するためにアルキル基 ( $\mathrm{R}$ ) の代りに $\mathrm{R}^{\prime} \mathrm{CH}_{2}$ の $\mathrm{R}^{\prime}$ の $E_{\mathrm{S}}$ 值を用いて[14]式のプロ ットを行ならと，より良好な直線関係の成立することが 見出された。この結果を図10にしめす。いずれのアルキ ルスチレンについても勾配 $(\delta)$ が同じであることは興味 深い。

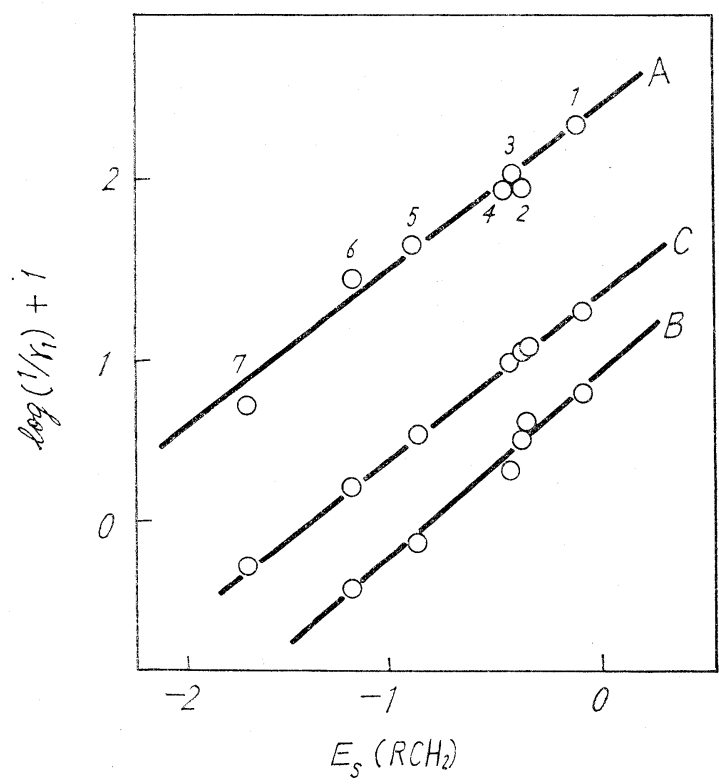

図 10 ポリアクリロニトリルラジカルに対する $\alpha-(\mathrm{A})$,

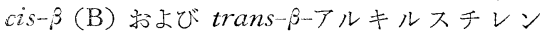
(C) の反応性

1. $\mathrm{CH}_{3}, 2 . \mathrm{C}_{2} \mathrm{H}_{5}$, 3. $n-\mathrm{C}_{3} \mathrm{H}_{7}$, 4. $n-\mathrm{C}_{4} \mathrm{H}_{9}$, 5. $i-\mathrm{C}_{3} \mathrm{H}_{7}$, 6. $s-\mathrm{C}_{4} \mathrm{H}_{9}, \quad$ 7. $t-\mathrm{C}_{4} \mathrm{H}_{9}$.

\section{IV.おおりに}

本稿では，ラジカル共重合データにもとづいてモノマ 一の䅉造と一般反応性の関係を $Q, e$ 論および置換基効 果の観点よりのベた。このほが, 生成ポリマーの構造 分析からモノマーの頭頭および頭尾付加やシンジオおよ びアイソ付加反応性の解析も進められている。また開始 剂の分解などで生じた低分子ラジカルとモノマ一の反応 速度も, 低分子ラジカルの付加反応と併行して研究され ている。このような場合には炭素以外の原子またはラジ カルの反志性も含まれ，系統的な研究は比較的少ないけ れども興味ある結果もみうけられる。適当な機会にまを めてみたいと思う。

(昭和 45 年 10 月 5 日受理)

\section{文献}

1) T. Alfrey, Jr., C.C. Price, J. Polymer Sci. 2 11, 101 (1947)

2) C.C. Price, Discussion of Faraday Soc. 2304 (1947)

3) T. Alfrey, J.J. Bohrer, H. Mark, "Copolymerization" Interscience (1951)

4) L.P. Hammett, J. Am. Chem. Soc. 5996 (1937)

5) L.P. Hammett, "Physical Organic Chemistry" McGraw-Hill (1940)

6) H.H. Jaffé, Chem. Rev. 53191 (1953)

7) 湯川, 都野, “有機反応機構の進歩 I” 槙畫店 (1958) p. 1

8）井本，“有機反応の理論 I” 共立 (1960)

9）大津, 工化 64 432 (1961)

10）鶴田，“高分子合成反応”日干刂工業新聞 (1959)

11) 鶴田, “Structure and Mechanism in Vinyl Polymerization”（鶴田， O'Driscoll 編) Dekker (1969), p. 27

12) K.F. O'Driscoll, T. Yonezawa, Rer. Macromol. Chem. 11 (1966)

13）鶴田, 化学と工業 221447 (1969)

14) L.J. Young, "Polymer Handbook" ed. by J. Brandrup and E.H. Immergut, Interscience (1968) p. II -341

15) N. Kawabata, T. Tsuruta, J. Furukawa, Makromol. Chem. 5171 (1962)

16) R.D. Burkhart, N.L. Zutty, Makromol. Chem. 67219 (1963)

17）大津，高分子生成反応 (池思ら編) 地人書館 (1968) p. 216

18) T. Ito, T. Otsu, M. Imoto, J. Polymer Sci. B 481 (1966)

19）大津，津田，福水，井上, 日化 89892 (1968)

20) A. Shimizu, T. Otsu, M. Imoto, Bull. Chem. Soc. Japan 381535 (1965)

21) T. Otsu, A. Shimizu, M. Imoto, J. Polymer Sci. A 3615 (1965)

22) H. Gilbert et al., J. Am. Chem. Soc. 781669 (1956)

23) J.B. Kinsinger et al., J. Appl. Polymer Sci. 9 429 (1967)

24) T. Otsu, B. Yamada, Makromol. Chem. 110 297 (1967)

25) B. Yamada, T. Otsu, J. Macromol. Sci. A 3 1551 (1969)

26) T. Otsu, B. Yamada, H. Yoneno, Bull. Chem. Soc. Japan 423207 (1969)

27) M. Kreisel, U. Grabatski, D. H. Kohn, J. Polymer Sci. A 2105 (1964)

28）太田，小林，小川，工化 711542 (1968)

29）大津, 山田, 野崎, 工化 701941 (1967)

30) C.C. Unruh, J.M. Laakso, J. Polymer Sci. 33 87 (1958)

31）野桜，第 4 回高分子化学の基礎之問題点に関する 
講座テキスト (1968) p. 15

32) K. Yasufuku, S. Hirose, S. Nozakura, S. Murahashi, Bull. Chem. Soc. Japan 402139 (1967)

33）山田，板橋，大津，Makomol. Chem. 投稿中。

34) J. Furukawa, T. Tsuruta, J. Polymer Sci. 36 275 (1959)

35）Kh. S. Bagdaryan 著，井本・二見訳 “ラジカル 重合の理論”朝倉 (1964) p. 196

36) たとえば, T. Otsu, M. Taniyama, M. Imoto, Memoirs of Faculty of Eng., Osaka City Univ. 10165 (1968)

37) C.C. Price et al., J. Polymer Sci. 183 (1946); 21015 (1947); 3772 (1948)

38) C. Walling, D. Seymour, K.B. Wolfstirn, $J$. Am. Chem. Soc. 701544 (1948)

39）山下雄也，小久保孝，有合化 27524 (1969)

40a) S. Iwatsuki, Y. Yamashita et al., Makromol. Chem. 89205 (1965); 102232 (1967); 104263 (1967); 工化 671470 (1964)； 68 1138, 1963, 1967 (1965); 69145 (1966); J. Polymer Sci. A-1 51753 (1967)

40b) T. Kokubo, S. Iwatsuki, Y. Yamashita, Macromolecules 1482 (1968)

41a) T. Otsu, H. Inoue, Makromol. Chem. 12831 (1969)

41b) T. Otsu, H. Inoue, J. Macromol. Sci. A 435 (1970)

42） T. Otsu, B. Yamada, S. Kusayama, 未発表

43) M. Imoto, M. Kinoshita, M. Nishigaki, Makromol. Chem. 86217 (1965)

44) K. Yokota, M. Kani, Y. Ishii, J. Polymer Sci. A-1 61325 (1968)

45) M. Imoto, T. Otsu, Y. Harada, Makromol. Chem. 65180 (1963)

46) 大津, 山田, 工化 72359 (1969)

47) 井本, 大津, 村田, 工化 661900 (1963)

48) B. Yamada, Y. Kusuki, T. Otsu, Makromol. Chem. 13729 (1970)

49）山田，楠木，大津，工化 72364 (1969)

50) S. Tazuke, N. Sato, S. Okamura, J. Polymer Sci. A-1 42461 (1966)

51) T. Otsu, Y. Kinoshita, A. Nakamachi, Makromol.Chem. 115275 (1968)

52) G.E. Serniuch, R.M. Thomas, USP 3, 183, 217 (1965) : BP 946, 052 (1964)

53) M. Imoto, T. Otsu, B. Yamada, A. Shimizu, Makromol. Chem. 82277 (1965)

54) S. Yabumoto, K. Ishii, K. Arita, J. Polymer Sci. A-1 71577 (1969)

55）池上，平井，第17回高分子討論会，22A08 (1968)

56) M. Hirooka, H. Yabuuchi, J. Iseki, Y. Nakai, J. Polymer Sci. A-1 61381 (1968)

57) 古川, 化学 25 41, 133 (1970)
58) 大津, 山本, 有合化 23643 (1965)

59) H.C. Brown, Y. Okamoto ,J. Am. Chem. Soc. 791913 (1957); J. Org. Chem. 22485 (1957)

60) G.A. Russell, J. Org. Chem. 231407 (1958)

61) Y. Yukawa, Y. Tsuno, Bull. Chem. Soc. Japan 32 960, 965, 971 (1959)

62) C. Walling, E.R. Briggs, K.B. Wolfstirn, F.R. Mayo, J. Am. Chem. Soc. 701537 (1948)

63) R. W. Taft, Jr., "Steric Effect in Organic Chemistry" ed. by M.S. Newman, Wiley (1956) p. 556

64) T. Yamamoto, T. Otsu, Chem. \& Ind. 1967787

65) C. H. Bamford, A. D. Jenkins, R. Johnston, Trans. Faraday Soc. 55418 (1959); 59530 (1963)

66) T. Migita, N. Morikawa, O. Simamura, Bull. Soc. Chem. Japan 36 980, 985, 992 (1963)

67) M. Imoto, M. Kinoshita, M. Nishigaki, Makromol. Chem. 94238 (1966)

68) 大津, 工化 701854 (1968)

69) 西垣, 木下，井本，工化 701938 (1967)

70) 西垣, 大阪市大学位論文 (1969)

71) T. Yamamoto, T. Otsu, J. Polymer Sci. A-1 7 1279 (1969)

72）高田善之ほか，日化年会

73) K. Tsuda, S. Kobayashi, T. Otsu, J. Polymer. Sci. A-1 b 41(1969)

74) T. Otsu, T. Ito, Y. Fujii, 未発表

75）大江，木下，井本，工化 69980 (1966)

76) T. Otsu, T. Ito, Y. Fujii, Bull. Chem. Soc. Japan 392257 (1966)

77) T. Otsu, T. Yamamoto, M. Hasegawa, 未発表

78) T. Yamamoto, Bull. Chem. Soc. Japan 40642 (1967)

79）山田，板橋，大津，未発表

80) G.M. Burnett, N. Grassie, Trans. Faraday Soc. 551042 (1959)

81) T. Otsu, T. Ito, M. Imoto, J. Polymer Sci. B 3113 (1965)

82) T. Otsu, T. Ito, M. Imoto, J. Polymer Sci. C (16) 2121 (1967)

83) T. Otsu, T. Ito, M. Imoto, J. Polymer Sci. A-1 4733 (1966)

84) T. Otsu, T. Ito, T. Fukumizu, M. Imoto, Bull. Chem. Soc. Japan 392259 (1966)

85) T. Otsu, K. Tsuda, T. Fukumizu, Makromol. Chem. 119140 (1968)

86) K. Chikanishi, T. Tsuruta, Makromol. Chem. 73231 (1964); 81211 (1965)

87) G.G. Cameron, G.D. Kerr, European Polymer J. 31 (1967)

88) K. Hayashi, T. Otsu, Makromol. Chem. 12754 (1969) 